\title{
1948 REFUGEES
}

\section{Proceedings of an international workshop, Hebrew University of Jerusalem Faculty of Law, 14-15 December 2016}

\section{Session 1: Introduction: Historical Origins and ConteXt}

\author{
The Birth of the Palestinian Refugee Problem, 1947-49
}

\section{Professor Benny Morris, Ben-Gurion University}

Professor Morris began by introducing the creation of the Palestinian refugee problem as a result of the 1947-49 war. The refugee problem, he considered, was one of the two most important consequences of that war, the other being the creation of the State of Israel, which changed the geopolitics of the region. The refugee problem, he said, was the major expression of the collapse of Palestinian society during the course of the war.

There has been controversy over the number of Arabs who were uprooted from their homes and lands. Israel maintained at the time that the figure was 500,000, while Arab countries claimed it was nearer 900,000 or one million. The United Nations (UN) in 1949-50 concluded that the real figure was just over 700,000. Today there are more than five million Palestinian refugees on UN records, including those who were alive in 1948 and their descendants: children, grandchildren and great-grandchildren. All other refugees in the world are handled by the UN High Commissioner for Refugees (UNHCR). It is only Palestinians who have a special agency of their own: the UN Relief and Work Agency for Palestine Refugees in the Near East (UNRWA).

Professor Morris maintains that there is a problem with definitions. The dictionary definition of a refugee is someone who has been uprooted from his or her country by war, persecution and similar, and moved or removed to other countries. About 500,000 of the original 700,000 Palestinian refugees were uprooted from their homes and were moved from one part of Palestine to another (for example, from Jaffa to the Gaza Strip or the West Bank), rather than to outside the country. Only about 200,000 were dispersed in the surrounding Arab countries. Moreover, the children, grandchildren and great-grandchildren of refugees are not recognised as 'refugees' (as in the case of, for example, the Sudeten Germans who were expelled from Czechoslovakia to Germany in 1945-46).

There have been two traditional narratives about the creation of the Palestinian refugee issue. The Arab view was that it resulted from a systematic expulsion as a result of a premeditated Zionist programme, in continuation of Zionist ideology. This is the dominant narrative in the Arab world. The Zionist view, formed in 1948, essentially claimed that the refugees fled for 
no good reason, or as a result of the war and fear, but not because of any expulsion plan or policy on the part of Israeli forces.

Professor Morris then turned to analyse the preconditions that facilitated the creation of the refugee situation. The first was the conflict, which had been ongoing for about 50 years, between Zionist settlers and the local Arab population, which sparked hatred towards Zionists in the Arab community. This came to a head in the Palestinian-Arab assault on Jewish communities at the end of 1947, which started the war. The war of 1947-49 was the last in a series of Arab assaults on the Jewish community in Palestine, which had started in 1920 and continued in 1921, 1929 and 1936-39. Cumulatively, these incidents created enmity among the Jews towards the Palestinian Arabs. The mutual hatred and enmity was the bedrock for the creation of the refugee situation.

The second precondition was the mixed populations, both inside towns (Tiberius, Haifa, Safed, Jerusalem) and between adjacent towns (such as Tel Aviv and Jaffa), and in rural areas. The war was fought mainly in the areas populated by Jews or where the populations were intermixed in varying degrees. In order to win a civil war of that sort, with neighbours shooting at neighbours and each village prohibiting traffic on roads leading to neighbouring settlements, each side had to clear out its neighbours. The Jews did this more successfully, and won. Had the Arabs done this successfully, they would have won. Both the Jewish and the Arab civilian communities, villages and town neighbourhoods served as the bases for their militias. However, it is worth remembering that the Arab side was the side that launched the war. ${ }^{1}$

On the Jewish-Zionist side, Morris added, there was another factor, which was an 'expulsionist' discourse. This evolved mainly during the 1930s, although traces of such thinking can be found before then in statements by Jewish spokesmen (such as Menahem Ussishkin ${ }^{2}$ ). The increase in antisemitism in Europe and the need for a safe haven for Europe's persecuted Jews, as well as the heightened animosity of the Arabs, all propelled an 'atmosphere of transfer'. This was augmented by the British Royal Peel Commission of 1937, which recommended the enabling, and even the compulsion of, transfer of communities as a necessary precondition for a stable two-state solution, each of the two emerging states in Palestine to be without large national minorities. ${ }^{3}$

The third precondition, according to Morris, was the weakness of the Palestinian community, which was unorganised, with no democratically elected institutions, with a leadership that did not enjoy legitimacy, and with an internally fractured socio-political structure between different clans. In this situation, the Palestinians entered a war in which they should not have participated. The community was ill-prepared to endure such a war; by comparison, the Zionists were much better organised and united.

Fourth, and perhaps the most important precondition according to Morris, was the war itself, which enabled the eviction of a large number of people.

\footnotetext{
${ }^{1}$ Benny Morris, One State, Two States: Resolving the Israel/Palestine Conflict (Yale University Press 2010) 35.

${ }^{2}$ Benny Morris, The Birth of the Palestinian Refugees Problem 1947-1949 (Am Oved 1991) 47 (in Hebrew).

${ }^{3}$ League of Nations, Report of the Palestine Royal Commission 1937 (Peel Commission) 389.
} 
Professor Morris then turned to describe the four stages of the emergence of the Palestinian refugee problem. During the first stage, between December 1947 and March 1948, most of the Palestinian elite - much of the middle and upper classes - fled to neighbouring countries or to the area which later became known as the West Bank. This group thus left the masses without leadership, and set them an example of fleeing. However, the masses did not have second homes in Beirut and Damascus, and were unable to afford to rent accommodation (unlike the fleeing upper and middle classes). Nonetheless, once the Zionist offensive started in early April 1948, the masses also began to flee - hence the initial flight of 75,000 of the middle and upper classes, which was significant and demoralising for the majority. The second stage lasted until June 1948, when about a quarter of a million Palestinians fled from towns and villages in the areas conquered by the Zionists when the latter went on the offensive in preparation for the expected pan-Arab assault. A few people were expelled, although the vast majority of these refugees fled out of fear of being caught up in battle. The third stage was the 'Ten Day Period' in July (9 July 1948 to 18 July 1948), during which Israeli forces launched offensives in different areas of the country. It was during this period that the major expulsion of the war occurred, when Israelis deported about forty to fifty thousand Arabs from Ramle and Lydda. Others fled when the Israel Defence Forces (IDF) conquered Nazareth and its surrounding area. The fourth stage, during October and November 1948, occurred when IDF brigades in the south conquered the Beersheba-Ashkelon area, and in the north, the central upper Galilee. This resulted in another 200,000 refugees. Thereafter, in the two years from November 1948 until the end of 1950, Israeli troops expelled tens of thousands of Bedouins along with townspeople and villagers (for instance, from Majdal\Ashkelon). ${ }^{4}$

Professor Morris concluded by addressing the issue of an expulsion policy. He contended that the Zionist side did not enter the war with a coherent plan or policy of expulsion and transfer, and did not reach a decision to unleash a policy of expulsion of 'the Arabs', either in the pre-state stage (before 14 May 1948) or afterwards. However, after four months of civil war with Arab attacks and with the prospect of a pan-Arab invasion in mid-May, from the beginning of April 1948 there was an 'atmosphere of transfer' in the Zionist community. Ben-Gurion supported transfer, although not everyone agreed with him. The Haganah and the IDF were told, or understood, that it was better to have fewer Arabs behind the front lines while anticipating an invasion by Arab armies or while fighting off the Arab invaders. ${ }^{5}$ In addition to these tactical considerations, Professor Morris added that from a strategic and political perspective, the Zionists came to understand during the course of the war that it was preferable to have fewer Arabs as they had fought against the creation of Israel and could be expected to be disloyal citizens of the new Jewish state in the future.

From April 1948 the idea of transfer took hold, although it was not universally adopted. Some officials and commanders were opposed to it and refused to expel Arabs (Ben Dunkelman, who commanded the 7th Brigade in July 1948 in Nazareth, for example). However, very few commanders actually had to expel anybody, as most of the Arabs had fled before fighting reached

\footnotetext{
${ }^{4}$ Morris (n 2) 328.

${ }^{5}$ Morris (n 1) 34.
} 
their doorstep. The crucial decision in this story was not of expulsion, as there was never any Jewish Agency Executive or Israeli Government or Haganah or IDF General Staff decision to expel 'the Arabs'; but there was a government decision of 16 June 1948, periodically reiterated thereafter, not to allow a mass refugee return. ${ }^{6}$ This was decided when about half of those who had fled had already become refugees. The IDF acted pursuant to this decision.

Professor Morris suggested that one form of proof for the contention that there was no preplanned decision or government-authorised policy of expulsion is that officers acted in different ways: some expelled, others did not, and none were punished in either case. At the end of the war, by late 1949 about 160,000 Arabs had remained in Israel (and acquired citizenship), making up 20 per cent of the state's population. Had there been an official systematic policy, they too would have been expelled. As early as November 1948, various officials claimed that there had been no official policy (in Operation Hiram, in late October 1948, when the IDF took uppercentral Galilee) and commanders adopted different approaches. ${ }^{7}$

On the Israeli side, Morris added, there is a myth about orders or advice given by Arab leaders to the local population to flee. This is not supported by historical documentation, and there is even evidence to the contrary. In May 1948, for example, there were orders from Fauzi Kawukji, Commander of the Arab Liberation Army, and from Jordan, for people not to leave; these leaders even threatened people with sanctions if they did leave. There is also evidence of orders not to leave given in March 1948 by the Palestinian national leader Haj Amin Al-Husseini to his people. There was therefore no policy of the Arab states or of the national Palestinian leadership encouraging or ordering the population to flee. However, Morris added, there were orders by Palestinian local leaders to evacuate. In some cases the instructions were for complete abandonment, as happened in Haifa on 22 April 1948, the rationale being that to stay would mark acceptance of Jewish sovereignty and be regarded as treacherous. In other instances orders were given by local leaders to villagers to send away women and children in order to remove them from combat or potential combat zones. The intention behind these orders was to strengthen the men who stayed to fight, but in practice they demoralised the resistance. Here and there, the invading Arab armies, the Jordanian and Egyptian armies, encouraged or ordered specific Arab villages to evacuate. ${ }^{8}$

In essence, Morris maintained, the main cause of the Arab plight were Zionist attacks on villages and towns, and the fear of such attacks. There were Jewish atrocities which prompted panic and flight, as occurred after Deir Yassin (in April 1948). (There were, of course, also Arab massacres of Jews, as occurred at the oil refinery in Haifa in December 1947). The massacre in Deir Yassin was widely broadcast in the Arab media for weeks, with exaggerated numbers and types of atrocity, leading the population to flee. However, what is crucial was the decision on Israel's part not to allow the refugees to return. Also crucial in the perpetuation of the Palestinian refugee problem was the Arab states' decision not to integrate the refugees. This contrasted with the

\footnotetext{
${ }^{6}$ Morris (n 2) 195.

${ }^{7}$ ibid 392.

${ }^{8}$ ibid $105-07$.
} 
situation in Europe after the Second World War, when Czechs, Poles, Russians and others absorbed Czech, Polish and Russian refugees. Both Israel and the Arab states, and the refugees themselves, perpetuated the refugee problem by refusing their absorption by the Arab states.

In the context of post-1945, pushing out populations and moving them around was regarded as morally acceptable behaviour, unlike today. Whole sets of populations were removed, and moved, almost without a murmur. This was seen by American, Russian and other leaders as something that would stabilise countries and actually maintain peace by preventing potentially explosive minority problems (of the sort that had destabilised Europe before the First and Second World Wars).

\section{The NaKba And the Palestinian Silence}

\section{Professor Mahmoud Yazbak, University of Haifa}

Professor Mahmoud Yazbak disagreed with many of the ideas and notions presented by Professor Morris, and began by suggesting a metaphor. He asked the participants to imagine an earthquake taking place; everyone runs for shelter; after a few minutes, the quake ends and they return to their homes. He drew a comparison with the Palestinian problem, and asked whether the Palestinian refugees would be allowed to return. It is an accepted notion that when people experience fear they have to flee in order to save themselves; when the event ends, they expect to return to their homes.

Professor Yazbak then turned to address the main issue of his presentation. ${ }^{9}$ He said that $N a k b a$ is a Palestinian term that indicates the total destruction that struck Palestinian society as a result of the establishment of the State of Israel in 1948. During the course of the 1948 War, the Zionist militias destroyed all the foundations of life in Palestinian society. After 15 May 1948 these militias constituted the Israeli army. In the course of the Zionist and Israeli military operations about 400 Palestinian towns and villages were destroyed, resulting in the expulsion and flight of about 80 per cent of the residents of the Palestinian regions on which the State of Israel was established. These residents became refugees, either within their homeland, as explained below, or outside, particularly in Syria, Lebanon and Jordan. As a result of the Palestinian Nakba, a group of Palestinians was created whose homes and villages were destroyed but who did not leave the region which had become the State of Israel. They are usually referred to as 'internally displaced persons' (IDPs) or 'internal refugees', and their number is at present estimated at 300,000 .

Although the IDPs remained in their homeland and acquired Israeli citizenship, the State of Israel took ownership of their property, lands and villages that had been systematically destroyed. This confiscation of property was based on the doctrine of 'absentee owners' that was invented

\footnotetext{
${ }^{9}$ Mahmoud Yazbak, 'The Nakba and the Palestinian Silence' in Sami Adwan and others, Zoom In. Palestinian Refugees of 1948, Remembrances (Republic of Letters 2011) 160.
} 
by Israeli law. ${ }^{10}$ According to this law, owners of Palestinian property lost title to their property if they were away from their villages or homes when the Israeli authorities conducted a census, notwithstanding that it was Israel that had expelled them and prevented them from returning to live in their homes. In the majority of cases the State of Israel transferred the expropriated property from its original owners to Jewish-Zionist institutions and set up Jewish settlements on the expropriated property all over the country. Most of the villages have been renamed with new Zionist names. An example is the Jewish settlement of Elyakim, which was established on the ruins of the Palestinian village of Umm al-Zinat in the Haifa region, the residents of which were expelled in 1948. Some of the residents became refugees outside the new Jewish state, and some joined the IDPs within the borders of the State of Israel. As in the case of the other Palestinians, they were forbidden from returning to their homes and property. Another group of Palestinians remained in their cities and villages. The IDPs acquired Israeli citizenship and, like other Palestinian citizens of Israel, were governed by military law until 1966.

The Palestinian cities of Safad, Tiberias, Haifa, Acre (Akka), Jaffa (Yafa), Lydda, Ramla and Bir A-Sabi'a (Beer Sheva), which fell into Israeli hands in 1948, suffered from the same destruction that struck the villages. The Israeli forces destroyed and razed the majority of the Arab neighbourhoods in these cities, systematically removed all signs of their culture and history, uprooted their residents and expelled them from their homes. The majority of those residents became refugees outside the borders of the State of Israel. These cities, and particularly Haifa and Acre, were not only urban centres; more importantly they were cultural and political centres where the majority of the Palestinian intellectuals and politicians lived. These cities contained the libraries, publishing houses, institutions of higher education, cultural centres and cafés, which had played an important role in the Palestinian cultural scene prior to the Nakba. All of these ceased to exist after the Nakba.

Professor Yazbak contended that the Nakba split Palestinian society and turned it into population groups dispersed over many places with no political, social or cultural leadership. Some of the Palestinians now lived in refugee camps on the West Bank of the Jordan River, which was annexed by Jordan and had become part of it. Some lived inside the Kingdom of Jordan, which at that time was referred to as the East Bank. In the Gaza Strip, which was under Egyptian rule, several refugee camps were established, and were occupied by those who had been expelled from Jaffa and the southern coast. The majority of the refugees from the northern part of Palestine, who had been expelled from the Galilee, found themselves in refugee camps in Lebanon and Syria, and some even reached Iraq. These groups were broken, destroyed, homeless, lacking work and education, living for years with no clear political vision. They suffered from the agendas and interests of the host countries, which sought to erase their identity, and sometimes to marginalise them, while ostracising them socially and politically. The refugees' rights to work, to education, residence and a dignified life were trampled upon.

${ }^{10}$ Absentee Property Law, 1950 (Israel), ss 1 and 4. 
Professor Yazbak went on to describe the ways in which the Palestinian refugees dealt with the situation. In the shadow of these difficult conditions, and in the absence of any Palestinian political leadership, the refugees started to seek out, by their own efforts, means of support, food, housing and, later, education. The refugee trauma was acute, as was the material and emotional loss that accompanied it. Their daily lives were fraught with intolerable challenges. In this situation there was no possibility of dealing with memories of the past or the question of 'how did all this happen to us?'. There were no scientific, technical or cultural tools to encourage the victims of the Nakba to make themselves heard, to recount or document their story. In many cases the defeated refugees who had been expelled from their homes avoided expressing their feelings and pain over what had been done to them and their families. This was the silence of the defeated and expelled refugees, who had lost their homeland and citizenship. Often they had no travel or transit documents, and certainly no political and national leadership who could lay out a road to alter the painful reality. This silence served the interests of the Middle Eastern countries that were directly connected with the question of the Palestinian refugees, but refrained from articulating the events of the Nakba and its horrifying stories.

The defeated, living in fear and insecurity in the refugee camps in a strange environment, did not wish to talk about their defeat. In addition, they were overcome by shame, guilt and torment, which only reinforced their silence. Photographs from the era show that the humiliating living conditions and the sense of alienation from the environment created shame on the part of the refugees towards themselves and others. The collective failure also symbolised their personal failure, which injured the pride of the patriarchal leadership, on both the general and the personal levels, and thus the silence was reinforced.

As a result of its displacement, exile and dispersal, Palestinian society broke down. Its cultural infrastructure was destroyed; the educated and intellectual elements were expelled and left their homes, taking nothing with them. The Palestinian intellectuals had no choice but to engage in arduous temporary jobs in order to feed their families, rather than to deal with the refugees' distress, describe their suffering and seek solutions for the situation. Alongside the inability of the intellectuals to fulfil their role and destiny, the host countries exercised complete control over the media and consequently controlled the voices that were allowed to be heard and what authors were permitted to write, in line with the interests of governments, which in many cases contradicted the interests of the Palestinian refugees.

The Palestinians who remained in their homeland within the borders of the State of Israel were under the control of military rule, as mentioned earlier, and clearly they were unable to tell of their disaster and express their hopes to the media, which were subject to the control of the military censor. Their voice was not heard for at least twenty years, and the story of defeat was not told. The silence of the defeated Palestinian society provided a golden opportunity for the victors to tell the story of their victory - namely the establishment of the State of Israel. The victors displayed pictures of heroism and miracles, with no regard for the results of their victory: they ignored the distress they had caused the Palestinians by uprooting them, killing and massacring them, destroying their villages and cities, taking over their property, and sometimes committing rape against their women (evidence for this exists in the diaries of Yosef Nahmani). In 
parallel with the silence on the part of Palestinians, the voice of Israel's propaganda rose up in the attempt to evade responsibility for its actions against a defenceless, leaderless people, who were unable to notice the dangers that threatened them. Israel presented itself as the soul of a modern miracle of David and Goliath and, in the absence of a Palestinian voice, the world expressed its admiration for the heroic acts of the modern Israel, which was perceived as a reflection of the developed Western countries.

Thus the Palestinian minority that remained within the borders of the State of Israel was cut off from its cultural and national core. For two generations it remained devoid of all cultural infrastructure, except for a minority who joined the communist party, the only legal political party that did not represent the interests of the Zionist institutions. This minority had no voice other than the newspaper Al-Ittihad, which described the living conditions of Palestinians in Israel. However, this voice was local and did not reach the international audience in order to tell of the consequences of the Nakba, the policy of expropriation of land and the disaster of the military rule over the minority. The situation of the refugees outside the homeland was no better. After the adoption of UN General Assembly Resolution 194(III), ${ }^{11}$ which stated that the refugees must be returned to their homeland and their problem resolved, they were forgotten. The refugee problem became limited to the provision of food and services by UNRWA.

In June 1967 Israel won a quick war against Egypt, Syria and Jordan. As a result of the conquest, its area increased two-fold or more. Israel occupied the Gaza Strip, the Sinai Peninsula, the West Bank including East Jerusalem, and the Golan Heights. Consequently, many refugee camps on the West Bank and in the Gaza Strip came under Israeli control. The year 1967 was a decisive year in Palestinian history. Palestinians holding Israeli citizenship met again with a large part of the Palestinian people in the West Bank and the Gaza Strip. Unlike in 1948 and as a result of Jordanian-Israeli political considerations, Jordan did not close the border with the West Bank after the 1967 war. Thus Jordan became a refuge for the transfer of Arab cultural creativity from Arab countries to the West Bank and from there to Palestinian towns and villages within Israel. This transfer significantly helped to disseminate cultural and political awareness among the Palestinian minority within Israel and in the West Bank.

Simultaneously, and as a consequence of the unexpected expansion of the State of Israel, the majority of the Israeli work force was employed in safeguarding 'security', and managing the occupation and other state affairs. Israel needed to construct new lines of defence along the Suez Canal, in the Golan Heights, and along the Jordan River, which separated the West Bank from Jordan. Now Israel had no choice but to exploit the Palestinian work force bearing Israeli citizenship, the majority of whom had been unemployed since the expropriation of their property and land. This initial event caused profound changes in Palestinian society within Israel, and subsequently also in the West Bank and in the Gaza Strip. As a consequence of the opening of the work market, the economic position of the Palestinians gradually improved; it accelerated following the 1973 war in which Israel, for the first time since its establishment,

${ }^{11}$ UNGA Res 194(III), Palestine - Progress Report of the United Nations Mediator (11 December 1948), UN Doc A/RES/194(III), para 11 . 
did not achieve a clear military victory. As a result of the accelerated economic improvement that followed the war, the first signs of a Palestinian bourgeoisie emerged. Parents invested in their children's higher education and, at the beginning of the 1980s, a new generation emerged of Palestinian intellectuals who had studied at Israeli universities. As the identity of this generation formed, the issue of the Nakba and the collective memory became a central component of the cultural and political identity of Palestinians in Israel, in the territories occupied in 1967 and in the Palestinian diaspora. The wall of shame was gradually breaking down. The Palestinian establishment set up the most significant website, 'Palestine Remembered', on which people began to tell of the Nakba, recording their memories and impressions, and building a comprehensive and all-embracing Palestinian narrative.

Professor Yazbak then turned to two examples which, he believed, exemplify the themes he had explored: two small villages beside Nazareth - Aylut and Ma'lul. ${ }^{12}$ In Aylut, a Muslim village, people were expelled. Yazbak maintained that there was a very well-documented massacre in the village, following which the villagers were expelled and they went to the church in Nazareth, where they stayed for three years. The church applied pressure on Israel to allow the villagers to return. However, by the time they were allowed to do so, all the land around the village, which had not been destroyed, had been confiscated and given to a new Jewish settlement.

In Ma'lul, which was composed of 50 per cent Muslims and 50 per cent Christians, the people were told by the IDF to leave for two or three weeks until order was maintained in the area. The villagers went to Nazareth and found temporary residence. However, after a few days the village was destroyed, and there were no houses to return to. The villagers lived as IDPs in Nazareth, and their property was confiscated and given to Jewish settlements nearby.

To summarise, Professor Yazbak stressed that according to the Palestinian narrative, the refugees, both internal and external, were expelled. Expulsion means not only forcing people to leave. They experienced acute fear and fled, legitimately expecting to return when circumstances allowed. The government's decision not to allow them to return was not expected. Yazbak emphasised that it must be remembered that many Palestinian citizens of the state are still refugees. For example, the people of Saffuri, only one kilometre from Nazareth, were expelled and moved to a nearby hill, overlooking Saffuri. Every day they see their village that was destroyed. If you ask them who they are, they answer they are refugees, and point to their old home; their Israeli citizenship does not change this fact. Professor Yazbak ended by stating that this issue of internal refugees must also be tackled, as well as the issue of external refugees.

\section{DisCUSSION}

A participant queried the use by Professor Morris of the Sudeten situation as an example of population transfer. The participant claimed that this example from the late 1940s should not be used

\footnotetext{
${ }^{12}$ Mahmoud Yazbak and Menachem Klein, 'Aylut and Ma'lul: A Tale of Two Palestinian Villages Before and After the 1948 Nakba and the Birth of Israel' in Adwan and others (n 9) 138-52.
} 
as a justification for the Palestinian case. First, the Allied powers agreed to expel the Germans from Czechoslovakia and Poland to punish them, as the Germans had lost the war. Second, the expulsion was carried out through a peace agreement. In the Israeli-Palestinian conflict, these conditions were not present. Moreover, the analogy is problematic in that the Germans were seen as enemies, unlike the Palestinians.

Professor Morris replied that he gave the Sudeten example not as a justification for expulsion, but to illustrate that in the realm of morality in the world at the time, population transfers were not absolutely immoral, especially if they served good and progressive causes. He added that the Palestinians were definitely perceived as the enemy as there was a war going on. The Palestinians, first, and then the Arabs in general, had assaulted the Jewish state. One could say, he added, that the Jews initiated the conflict by invading Palestine in the 1880 s and settling there, and therefore 1948 was only one chapter in the conflict. However, the better view is that the 1948 War began after the Palestinians rejected the Partition Plan on 29 November $1947^{13}$ and started to attack Jews. In this context, they were the enemy, and if enmity is justified in expelling Sudeten Germans, then it was also legitimate to expel Palestinians as they assaulted the Jews. The comparison with Sudeten therefore works against the participant's argument.

The same participant also raised doubts over another matter - that of Jews in Palestine who were ordered to leave their homes during the war and were allowed to return afterwards. What could be the difference between the two communities that would justify disparate treatment? The participant claimed that the Jewish decision not to allow refugees to return and the Arab decision to not absorb them fully should not be put on the same plane - either morally or legally.

Professor Morris replied that some 70,000 Jews were displaced during the war, representing about 10 per cent of the Jewish population at the time. Some were captured by Arab armies (Gush Etzion, Old City of Jerusalem) and expelled; others moved away from frontlines. In every case in which the Arabs conquered a Jewish settlement, they razed it to the ground systematically. This is no different from what the Zionists did, only that destruction by the Zionists was not so systematic and many Arab towns remained untouched. In most cases, Jews moved back to their homes after the war, and in some cases were resettled in new places.

With regard to the responsibility of the Arab countries, Morris maintained there might not have been a legal requirement to absorb the refugees, but there was certainly a moral requirement. The Arab countries were brethren, and should have taken in the refugees. The Arab states refrained from doing so in order to use the refugees as an instrument against Israel in propaganda and guerrilla warfare. They had an interest in leaving the refugees weak and impoverished in the following decades. Generally, in world history, aggressors often pay a price. The Arabs were the aggressors in the context of the 1948 War, and this is why they paid a price. Morris claimed that a different approach by the Arab states could have produced a more peaceful situation.

Another participant offered a different perspective. He referred to the first phase that had been outlined - the flight of the Palestinian intelligentsia, in relative calm and peace, to settle in the

\footnotetext{
${ }^{13}$ UNGA Res 181(II), Future Government of Palestine (29 November 1947), UN Doc A/RES/181(II).
} 
neighbouring states. He said that this indicated that there were in fact different statuses given to different refugees. He asked how this could be reconciled with the extensive destruction of the cultural and political society that Yazbak described, which included the external refugees. The participant wondered whether distinctions could be drawn between how the diasporic communities re-created themselves and rebuilt their cultural life, in relation to works of the intellectuals and the diverging reactions of the host states.

Professor Yazbak replied that the Palestinian elites had had an experience of departure and return during the Arab revolt of 1936-39. Part of the revolt at the time was even directed against the Palestinian elite, which felt threatened and left for Beirut, Damascus and Nablus until the situation calmed down. People had the experience that they could leave and come back afterwards. In Haifa, for instance, the downtown is the Arab town, and the upper part was Jewish. In the seamline between them, some families (the Shiblak family, for example), who were in the frontline and had been shot at by Zionist militants, left. They wanted to return after few months, and were refused.

Professor Yazbak added that at the time, the Palestinians had no armed forces and were left in the hands of the Jews. People in Nazareth were not expelled only because Ben-Gurion decided so, while in other cases he did not oppose expulsion. Yazbak stressed that the policy of preventing return is tantamount to expulsion. Blaming the Jordanians and others is wrong as Palestinians are individuals whose rights have been violated and who deserve compensation. Those responsible for this must take responsibility. After so many years, the IDPs must be treated with justice in order for the whole issue to be resolved.

Another participant highlighted that Professor Morris dispels the theory and the myth that the flight followed orders by Arab leaders. This knowledge had not trickled down to the entire population. Second, even if historically there had been no plan for expulsion, today it might be misleading to say that there was an expulsion, as today there is a different conception of the phenomenon. After two or three decades of jurisprudence by international tribunals, we know that a plan is not necessary for this conduct to be wrongful and for it to entail the responsibility of leaders. When actions happen in such a widespread manner - many violations across time and space - this could be enough to generate responsibility. In the context of 1948, actions of expulsion by private individuals on their own initiative, even without orders, when they occurred in many cases across time and space, could engender responsibility of the leaders by way of command responsibility - namely that they should have known what was being perpetrated, even if they had no actual knowledge. The historical narrative should be nuanced with the legal context, since not having a plan is not necessarily enough to avoid responsibility. The participant added that although UN General Assembly Resolution 194(III) suggests two alternative options - return or compensation - the right to return has never been taken off the table from the point of view of the UN.

Another participant commented that Professor Morris's analysis, according to which there had been no plan for expulsion, lacks the crucial element of Jewish immigration to Palestine. When thousands of people from Europe and all around the world arrive, a space for them in which to live must be found. At the time, there was a severe lack of housing, and the property of Palestinians who fled answered this problem. This needs to be taken into consideration when 
thinking about the motives of the Jewish leadership. The participant added that it is inaccurate to use the fact of Palestinians remaining in Israel as proof that there had not been a systematic plan, as until 1966 that population was under military rule without any entitlement to rights; and also as Ben-Gurion used that population, when Israel applied to the UN in 1948, to show that Israel was a democratic state, as the Palestinians who stayed would be able to participate in the elections.

To this Morris replied that after 1948 Israel perceived the Arabs who remained there as a potential fifth column, which is why there was military rule. Israel had not forgotten the hostility and violence shown by the Arabs in Palestine against Jews, and it was still surrounded by very hostile Arab states. Maybe this should not have persisted until 1966, but the suspicions themselves were legitimate. He also stressed that it is correct that the rights of Israeli Arab citizens - mainly freedom of movement - were curtailed, but they had voting rights and were not disenfranchised absolutely. Additionally, it is wrong to put the starting point of the war at 15 May 1948, when the Arab armies invaded, and say that before that expulsion took place. There had been a civil war between the communities before then, launched by the Palestinians, and in which some 1,700 Jews were killed - 0.3 per cent of the population. Morris stressed that notwithstanding the value of historical narratives, these are factual truths that cannot be disregarded.

Morris further stated that he understood the focus on the morality of return, and agreed that every refugee has the moral right to return to his or her home in a post-war situation. However, the problem is not one of individual morality, but of real politik. The issue is the 700,000 who participated in a war against Israel. Even if not every one of them individually contributed, they were actively engaged as a people. The return of a population of this size would have constituted an Arab majority at the time. This was geopolitically impossible. It is justified on an individual basis: people had the moral right to return, but there is also the morality of states. This applies also to the five million so-called refugees of the present day, as their return would essentially wipe out the Jewish state.

Another participant added that the way in which the Sudeten example was mentioned was incomplete, as there are many other examples in the 1945-49 era in Europe, in both intra- and inter-state conflicts. In some cases the numbers reached hundreds of thousands - for example, in the case of Hungarians expelled from Romania, or Czechs and Slovaks, and in the Balkans. None of these populations were given the right to return or resettle. It is unlikely that they had expectations of return, given the historical context. In part this was as a result of the Cold War, but not always. All of these societies had moved on.

With regard to the point made by Professor Morris, the participant also raised questions about the status or responsibility of Palestinian individuals or the community as co-belligerents with the Arab nations. This could relate to Article 1 of the Palestinian National Charter, ${ }^{14}$ which presumably represents the will and self-determination of the Palestinian people. The Article states that the Palestinians are an integral part of the Arab world.

\footnotetext{
${ }^{14}$ The Palestinian Liberation Organization, 'The Palestinian National Charter', Resolutions of the Palestinian National Council, 1-17 July 1948, art 1.
} 
Another participant disputed that the legal situation at the time was not as clear as other participants have tried to suggest. International norms at that time were already more complex than to claim that the transfer of a population was lawful. The Charter of the International Military Tribunal at Nuremburg listed transfer of a population as a war crime and a crime against humanity; ${ }^{15}$ the Universal Declaration of Human Rights of December $1948^{16}$ was formulated at that time and noted the right to return to one's home; and the Fourth Geneva Convention of $1949^{17}$ is also very clear on the limits of transfer of a population in certain situations (it must be temporary and must allow return). States were discussing and negotiating the norms at that time.

The same participant also maintained that it was not only imprecise but also counterproductive to tell Palestinians that transfer was common at that time, for the same reason that it is irrelevant to argue that slavery was common at another time. There is a general trend in mature liberal democracies to acknowledge the past (for example, Canada, ${ }^{18}$ the United States and Australia) and recognise the reprehensible practices of the past.

Another point made by the same participant was that in order to move forward, politics, justice and the law must be reconciled in a productive way. One way is to find a normative convergence around narrative; another is to find a narrative-free, normative-free technical legal framework. The history of refugee negotiations (such as in Taba) suggests that this issue has bedevilled the process.

Another participant added that Professor Yazbak's earthquake analogy is inaccurate as it ignores the political context. There was no natural disaster, but a war instigated by the Arab side. There is a responsibility of a society, not only of individuals. When societies go to war, one does not go around and examine individual responsibility. The political context is also relevant to the fact that there was no peaceful resolution of the conflict because the Arabs rejected the Partition Plan and refused to recognise Israel. The same participant also noted that the meaning of 'return' should be scrutinised as Palestinian political thought and the literature of the time suggest that they wanted to undo Israel rather than return peacefully.

The speakers then argued about the level of responsibility on the part of the Palestinian population. Professor Yazbak addressed the issue of individual responsibility, and said that for a long time there was no documentation about the Nakba on the Palestinian side. Today, however, when there are more memoires in place, it is evident that the majority of Palestinians did not participate in the war, and that the main reason they left was the atrocities committed by Jews. Professor

\footnotetext{
${ }^{15}$ Charter of the International Military Tribunal for Germany - Annex to the Agreement for the Prosecution and Punishment of the Major War Criminals of the European Axis (entered into force 8 August 1945) Nuremberg Trial Proceedings 1, art 6.

${ }^{16}$ Universal Declaration of Human Rights, UNGA Res 217A(III), 10 December 1948, UN Doc A/810 (1948), art 13(2).

${ }^{17}$ Geneva Convention (IV) relative to the Protection of Civilian Persons in Time of War (entered into force 21 October 1950) 75 UNTS 287 (GC IV), art 49.

${ }^{18}$ Statement of Apology to Former Students of Indian Residential Schools, Document on behalf of the Government of Canada, 11 June 2008, http://www.aadnc-aandc.gc.ca/DAM/DAM-INTER-HQ/STAGING/textetext/rqpi_apo_pdf_1322167347706_eng.pdf.
} 
Morris disagreed, and claimed that historical evidence shows that every Palestinian village was involved in some way in armed struggle.

Professor Morris said that compensation has been offered repeatedly, for instance, by the Clinton administration and also by the Israeli government. However, compensation must be given within the framework of an overall settlement. It is wrong to view things from an individual perspective, and the focus is between societies and states. Palestinians have to take responsibility over what their leadership did. What happened to them was a result of this conflict, even if not all individuals were involved. Not taking responsibility is to avoid the main issues. He also rejected the comparison with Australia, where the indigenous population was oppressed, discriminated against and destroyed. In the Israeli-Palestinian case the situation was a national conflict between two peoples, two national movements fighting each other.

\section{Session 2: The Palestinian Refugee Problem in International CONTEXT}

\section{Palestine Refugees and the Challenges in Seeking Legal Protection Outside the REGION}

\section{Professor Guy Goodwin-Gill, University of Oxford}

Professor Goodwin-Gill began by pointing out that international law and organisation relating to refugees now had close to a hundred years behind it, yet states have traditionally seen the refugee phenomenon as essentially temporary. With a few exceptions, this perspective has dominated their approach since the first League of Nations High Commissioner for Russian Refugees was appointed in 1921.

Another issue has been the humanitarian-political dichotomy, which has persisted but has never been adequately addressed, despite the efforts of various individuals. For example, in 1935 James Grover McDonald resigned as High Commissioner on the ground that the German refugee problem was not only humanitarian, but also political. If the international community is not prepared to tackle the refugee problem on a political level, a purely humanitarian approach is unlikely to succeed. An additional tension also exists in the practice of organisations and states to approach refugees in terms of groups and categories, rather than as individuals with rights.

Following the massive population displacements of the Second World War, the UN General Assembly set up the International Refugee Organization in 1946. This organisation was soon caught up in the politics of the Cold War, and although it was already in existence when the Israeli-Palestinian refugee crisis arose, it was not mandated to deal with it. This responsibility was given to UNRWA and the UN Conciliation Commission for Palestine, which were established by the General Assembly in 1949. During the period 1948-50, the UN began to think about replacing the International Refugee Organization, and it was decided to create the Office of the United Nations High Commissioner for Refugees (UNHCR) as a subsidiary organ of the General Assembly. To complement this agency, which was initially intended to be 
non-operational, a new convention was proposed, building upon the treaty experience of the 1920s-40s, and the 1951 Convention relating to the Status of Refugees was negotiated and signed in Geneva in July of that year. ${ }^{19}$

The other major issue at this time, of course, was the Israeli-Palestinian conflict. During the debates in the General Assembly between 1948 and 1950, it was clear that many states did not want the issue of the Palestinian refugees to be lost within measures relating to refugees generally. There were several reasons for this. The Arab states, in particular, saw the problem essentially as the responsibility of the UN, because of the latter's adoption of the Partition Resolution. In their view, and because of this involvement, the UN should retain specific accountability for Palestine refugees. States were keen to ensure that the Palestinian refugees should enjoy continuity of protection and rights under the Refugee Convention, should UNRWA protection and assistance come to an end. ${ }^{20}$

The debates in the UN also reflected the idea that refugees were a temporary phenomenon, and the confident but misplaced expectation that the Palestinian issue would be settled in the near future. Nevertheless, from the start the General Assembly accepted that Palestinians were refugees and no one questioned it. Article $1 \mathrm{D}$ of the Refugee Convention provides that it 'shall not apply to persons who are at present receiving protection or assistance' from UN agencies other than UNHCR. The wording does not specifically refer to 'Palestine refugees' but that was the understanding at the time. Article 1D is sometimes referred to as 'excluding' Palestinian refugees, but this is a misunderstanding. In fact, Article 1D provides that 'when such protection or assistance has ceased for any reason, without the position of such persons being definitively settled ... these persons shall ipso facto be entitled to the benefits of [the] Convention'. So, rather than being an 'exclusion' clause, Article 1D of the Refugee Convention is a 'contingent inclusion' provision.

From the perspective of a lawyer or a state, Article 1D raises a number of interpretative challenges, not the least being as a result of the Palestinian issue remaining unresolved. ${ }^{21}$

\footnotetext{
${ }^{19}$ Convention relating to the Status of Refugees (entered into force 22 April 1954) 189 UNTS 150 (Refugee Convention).

${ }^{20}$ See generally Guy S Goodwin-Gill and Jane McAdam, The Refugee in International Law (3rd edn, Oxford University Press 2007) 149-61, 436-38, 458-61; Lex Takkenberg, The Status of Palestinian Refugees in International Law (Clarendon Press 1998).

${ }^{21}$ Case C-31/09 Bolbol v Bevandorlasi es Allampolgarsagi Hivatal [2010] ECR I-5572; Case C-364/11 El Kott v Bevandorlasi es Allampolgarsagi Hivatal, Judgment, 19 December 2012; Said (Article 1D: Interpretation) v Secretary of State for the Home Department [2012] UKUT 413 (Immigration and Asylum Chamber); $A D$ (Palestine) [2015] NZIPT 800693-695; Office of the UNHCR, Note on the Applicability of Article 1D of the 1951 Convention relating to the Status of Refugees to Palestinian Refugees, 2 October 2002, http://www.refworld.org/docid/3da192be4.html; Office of the UNHCR, Note on the Interpretation of Article 1E of the 1951 Convention relating to the Status of Refugees, 1 March 2009, http://www.refworld.org/pdfid/49c3a3d12.pdf; Office of the UNHCR, Note on the UNHCR's Interpretation of Article 1D of the 1951 Convention relating to the Status of Refugees and Article 12(1)(a) of the EU Qualification Directive in the Context of Palestinian Refugees Seeking International Protection, 1 May 2013, http://www.refworld.org/docid/518cb8c84.html; Office of the UNHCR, Call for Comments on: Applicability of Article 1D of the 1951 Convention relating to the Status of Refugees to Palestinian Refugees, http://www.unhcr.org/en-au/protection/globalconsult/59ae98b24/ call-comments-applicability-article-1d-1951-convention-relating-status.html.
} 
The term 'at present receiving', for example, is inherently ambiguous. It is not clear whether it refers to those receiving protection on 1 January 1951 (when UNHCR came into existence), 28 July 1951 (when the Refugee Convention was opened for signature), or 22 April 1954 (when the Refugee Convention came into force). Similarly, there is no clear definition of a Palestine refugee, and therefore of the scope of application of Article 1D ratione personae. It could require reference, among others, to UN General Assembly Resolution 194(III), ${ }^{22}$ Resolution 2252 (ES-V) of $1967,{ }^{23}$ or to the general practice of UNRWA. Moreover, the approach of UNRWA to the definition has been essentially operational, geared towards providing relief and assistance, rather than defining eligibility for refugee status in the sense of Article $1 \mathrm{~A}(2)$ of the Refugee Convention.

One aspect that was not anticipated by the drafters in 1951 is the increase in mobility for refugees, which has emerged as an issue for many European and other states. Not surprisingly, this has led to uncertainties as to the interpretation of Convention terms such as if such protection ceases' or 'presently receiving'. While this might refer to the end of UNRWA's operations, it was not clear that it referred to refugees leaving the areas of UNRWA's ongoing operations. At the same time, the protection due to the refugee has become 'individualised' and a matter of rights. States still see asylum as an exception to their sovereign power to decide on the entry and removal of non-citizens, and are as concerned today as they were in 1951 about having perhaps signed a 'blank cheque' on the admission of refugees. Consequently, they tend to argue that the 'right to asylum' should be interpreted restrictively.

The phrase '[w]hen such protection or assistance has ceased for any reason' also offers plenty of scope for interpretation. On first reading, a Palestinian refugee whose protection ceases for any reason, without his or her situation being resolved, appears to be entitled to the benefits of the Convention. Does this mean that a Palestinian can simply choose to leave UNRWA's area of operations and thereby become entitled to the benefits of the Convention? One approach, with support in European jurisprudence, is to look for evidence of involuntary decisions, such as political or security reasons beyond the control of the individual, and which underlie his or her reason for leaving or inability to return. This approach may then be qualified by consideration of the additional question, whether the individual concerned was receiving or eligible for UNRWA assistance. Such an approach may cause many Palestinians to 'fall between the cracks', for example, if they are self-sufficient and thus outside the UNRWA safety net.

Where does that leave us today? Until there is a definitive resolution of the conflict, and in the absence of a major shift in the General Assembly and the Security Council, Palestinian refugees are a class identifiable as such by reference to certain historical facts. However, this is also a group in which membership is nevertheless open, and which may include the descendants of the refugees of 1948 and 1967. In the absence of a durable solution, protracted refugee situations can commonly lead to statelessness and the transmission of refugee 'status' through generations as Article 1D says, until such time as their position is 'definitively settled'.

\footnotetext{
${ }^{22}$ Res 194 (n 11).

${ }^{23}$ UNGA Res 2252 (ES-V), Humanitarian Assistance (4 July 1967), UN Doc A/RES/2252 (ES-V).
} 
The jurisprudence does not offer an easy solution for Palestinian refugees outside the region. This may not be intentional, but is rather a result of the ways in which ambiguous words and phrases have been interpreted, particularly in the light of states' other concerns.

\section{Refugees and Return in Prolonged Occupations}

Professor Eugene Kontorovich, Professor of Law, Northwestern Pritzker School of Law

Professor Kontorovich addressed the issue of refugees and settlers in prolonged occupation in a broader and comparative context, to find points of potential application to the Israeli-Palestinian refugee issue. He noted the difficulty in finding perfect points of comparison because of the prolongation of the Palestinian refugee issue, as defined by its own terms, for nearly seventy years. There are no comparable situations of a refugee population being recognised as such and given legal status, including an intergenerational definition of refugees; the demands of return enduring for such an extended period are also exceptional. Nonetheless, these various cases may still shed insights into this current conflict.

One of the most contentious issues in the Israeli-Arab conflict is the fate of Arab residents of Palestine who fled from the territory during Israel's War of Independence. ${ }^{24}$ Another major issue is the question of Jewish settlers in the West Bank (and formerly Gaza). While considerable attention has been focused on these issues in the Israeli context, there is much that can be learned by examining their treatment in other contexts. Such state practice is an important source of determining the content of international norms.

\section{Refugees Return as Settlers Stay}

Numerous conflicts combine both refugee and settler issues. Notably, conflicts in which there have been prominent international demands for a 'right of return' for one party have also involved settlement activities by the other. Thus in Western Sahara, Northern Cyprus, and Nagorno-Karabakh the solutions put forward by the international community contemplate some degree of refugee return on the part of the Sawahari, Greek Cypriots, and Azeris. These situations, however, also involve large-scale settlement activity in the occupied territory by the other party. Furthermore, the same international solutions that allow for some right of return also contemplate all of the settlers remaining in the occupied territory (as well as recognising a bilateral right of return for nationals of the occupying power - that is, Turkish Cypriots to Southern Cyprus). This suggests that refugee return - a remedy for population displacement - as a practical matter is connected to a policy of not creating new displacements, including of settlers.

The first interesting case is the Soviet occupation of the Baltic states - Lithuania, Latvia and Estonia - from the middle of the Second World War until the demise of the Soviet Union. These

\footnotetext{
${ }^{24}$ Their descendants through the male line are uniquely regarded as 'refugees' despite not having fled from a conflict, and thus not meeting the general definition of refugee.
} 
areas were annexed and incorporated as part of the Soviet Republics but were treated by a small but influential international community, including the US, as occupied territories throughout the period. Upon regaining their independence, the Baltic states characterised the period of Soviet Union rule as a period of occupation. This became an important part of the national rhetoric as well as jurisprudence. During the Soviet invasion of the Baltics and the subsequent guerrilla warfare, which lasted from about 1944 to 1956, around 150,000 Balts were expelled from the territory by the Soviet Union to other areas of the Soviet Union, and became refugees. During the Soviet occupations, large numbers of Russian 'settlers' moved into the Baltic states, sometimes making up more than half of the local population. Upon independence, remediation of the effects of the occupation formed part of the national agenda. This had two aspects. One was the taking of certain mild measures to pressure or coerce the Russians to leave; the other involved measures that allowed a type of repatriation for ethnic Balts to the area. Interestingly, the borders of the three Baltic states had altered completely. Nonetheless, in practice, the return of the people was limited to the sovereign Baltic state territories.

In practice, not many people moved in either case because the populations had become well integrated. An interesting feature of this example, which may be proposed as a possible solution to the Palestinian refugee issue, is that the refugees return not specifically to a new state created as part of a political resolution, but rather to the territory where they have ancestral links.

The second case is the Moroccan invasion of Western Sahara, which resulted in a fairly significant population movement, with large numbers of refugees and internally displaced persons. The efforts by the international community to resolve the Moroccan occupation in the Western Sahara - the Baker Plans of the late 1990s and early 2000s - dealt with the refugee issue and allowed the refugees to return in some number. However, at the same time, Morocco transferred a large number of Moroccans into the territory. One issue that arises from the Baker Plan, which is common to many situations, is that the conflict resolution feature of the limited return of refugees is coupled with the conflict resolution feature of the non-expulsion of settlers. The plan was not thought to be very successful because there were a significant number of settlers in the area, which reduced incentives for the refugees to return.

Similarly, in the Cyprus dispute, there were provisions for a very limited and calculated return of Greek-Cypriot refugees to the northern parts of the island in order to avoid altering the majority Turkish population resident there. When the conflict occurred in 1974, the Greek-Cypriots from the northern parts fled to the south while the Turkish-Cypriots from the south fled to the north. The Annan plan ${ }^{25}$ recognised both groups who had fled from their lands, all the provisions being contingent on the political solution. Unfortunately, the Greek-Cypriots did not agree to this plan, and later there was a complete collapse of a formal peace process. This example illustrates how a refugee issue, although not the only issue in this case, can make a peace process more difficult to achieve.

It bears noting that none of these protracted occupations, which involved internationally backed demands for the return of refugees, has resulted in a resolution. Indeed, the demands

${ }^{25}$ The Comprehensive Settlement of the Cyprus Problem, United Nations Proposal, 31 March 2004 (Annan Plan). 
of the refugees played a prominent role in frustrating any possible solutions. Moreover, there has never been resettlement of refugees more than 34 years after a conflict - even that unusual example saw refugees (from Burundi) resettled in a third country. ${ }^{26}$ Thus the nearly 70 -year-old demand for a solution to the Palestinian refugee problem has absolutely no parallel in international practice.

\section{Can Settlers be RefugeEs?}

The issue of settlers in occupied territory and refugees intersects in an unexpected way. In several situations around the world, refugees from a conflict have been settled by an occupying power in territory that it occupies. Does absorption of refugees violate Article 49(6) of the Fourth Geneva Convention $^{27}$ - that is, can accepting refugees also constitute illegal settlement activity? Or, to put it differently, does a refugee's right to safe asylum outside his or her home country not apply to occupied territories? State practice suggests the answer to these questions is 'no'.

By way of example, tension between the Khmer majority and the Vietnamese minority in Cambodia dates back over several centuries. During the Khmer Rouge takeover and associated turmoil in Cambodia in the 1970s, the Vietnamese were subject to discriminatory measures and finally pogroms and expulsions which led almost all of the ethnic Vietnamese population to flee to Vietnam. ${ }^{28}$ In 1978 Vietnam invaded and occupied Cambodia. Several hundred thousand Vietnamese settlers came to Cambodia during the decade of occupation. The settlers fell into two groups: as many as half were refugees returning to Cambodia after having fled from violence in the previous decade, while the other half consisted of a 'new migration of Vietnamese settlers who established themselves as shop owners, vendors, farmers or fishermen'. ${ }^{29}$

The UN General Assembly took critical note of the Vietnamese settlers, but refused to describe the situation as a violation of Article 49(6), as it regularly does with regard to Israeli settlers. The fate of the Vietnamese settlers was raised by Cambodian representatives in the multilateral Paris peace negotiations held between 1989 and 1991. The Khmer representatives were extremely hostile to the Vietnamese settlers, arguing that their continued presence would de facto perpetuate the Vietnamese occupation, and that they would serve as puppets of Vietnam. ${ }^{30}$ These arguments were rejected by the peace brokers.

\footnotetext{
${ }^{26}$ Andrew Kent, 'Evaluating the Palestinians' Claimed Right of Return' (2012) 34 University of Pennsylvania Journal of International Law 149, 231.

${ }^{27} \mathrm{GC}$ IV (n 17) art 49(6).

${ }^{28}$ Ramses Amer, 'The Ethnic Vietnamese in Cambodia: A Minority at Risk' (1994) 16 Contemporary Southeast Asia 210, 216-18.

${ }^{29}$ M Giovani Merli, 'Estimation of International Migration for Vietnam, 1979-1989', Seattle Population Research Center, Working Paper No 97-04 (1997) 6-9.

${ }^{30}$ Steven Erlanger, 'In Fear, Settlers from Vietnam Leave Cambodia', The New York Times, 23 September 1989; Michael Haas, Genocide By Proxy: Cambodian Pawn on a Superpower Chessboard (Praeger 1991) 200, 222 (noting that other countries involved in the peace process rejected Cambodian demands that it should include 'just solution' to the issue of 'foreign settlers').
} 
The Vietnamese settler refugees also happen to be one of the few examples where scholars have addressed the applicability of Article 49(6) of the Geneva Conventions outside the Israeli context and concluded that it does not apply to settler refugees. ${ }^{31}$ In 1991, pursuant to the Paris Peace Accords signed in 1990 with various Cambodian factions, Vietnam withdrew its troops in favour of a transitional UN regime, but was not required to withdraw its settlers.

Another example is the Karabakh conflict. The core of the Armenian claim to the area lies in the Armenian population in the area. During the war, a million Azeris fled from Armeniancontrolled territory, and large numbers of Armenians fled from Azerbaijan. As a result, Karabakh now has an almost entirely ethnic Armenian population, but the fate of Azeri refugees remains a major issue for Azerbaijan. Against this background, Armenia has encouraged migration to the occupied territories, particularly those under clearly de jure Azeri sovereignty, such as the remote Lachin corridor. Azerbaijan has strongly and repeatedly protested against these moves and denounced them as a violation of international law, and of Article 49(6) in particular. ${ }^{32}$ A significant number of settlers were ethnic Armenian refugees from various conflict zones. A large number of them are those who fled from Azerbaijan during the conflict. ${ }^{33}$ These refugees constitute perhaps 20 per cent of the population of the occupied territory. Since then, there have been significant efforts to attract ethnic Armenians from the diaspora, with a particular emphasis on refugees. Thus Azerbaijan has accused Armenia of purposefully settling Armenian refugees from Syria in Karabakh. ${ }^{34}$ Despite Azerbaijan's condemnation of this activity, the international community has not in any way suggested it is illegal.

The Russian occupied area in Abkhazia also has a similar programme to encourage ethnic Abkhaz to settle in the occupied territories. The international community has largely avoided characterising the territorial situation in any legal way, ${ }^{35}$ but there is ample consensus that the territories remain under Russian belligerent occupation. ${ }^{36}$ Since the war, the nominal Abkhazi authorities have engaged in a centralised, state-sponsored programme to settle people in the territory. The explicit purpose of the programme is to change the demographics and, in particular, to reduce the ethnic Georgian percentage of the population. ${ }^{37}$ The occupation authorities have

\footnotetext{
${ }^{31}$ Steven R Ratner, 'The Cambodia Settlement Agreements' (1993) 87 American Journal of International Law 1, $20 \mathrm{n} 119$ ('The applicability of art. 49(6) to ethnic Vietnamese who had lived for many years in Cambodia is not clear from either the text or authoritative commentary'); GC IV (n 17).

${ }^{32}$ Adil Baguirov, 'Outside Witness Testimony for FY2014: Written Statement for the Record', US House of Representatives Committee of Appropriation, 1 March 2013, http://docs.house.gov/meetings/AP/AP04/ 20130314/100434/HMTG-113-AP04-Wstate-BaguirovA-20130314.pdf.

33 'Refugees and Internally Displaced Persons (IDP) in Nagorno Karabakh', Office of the Nagorno Karabakh Republic, May 2006, http://www.nkrusa.org/nk_conflict/assets/Fact_Sheet_on_Refugees_\&_IDP_2006-05-16.pdf. 34 'Syria Armenians Move to Nagorno-Karabakh: Azerbaijan', Hurriyet Daily News, 2 October 2013, http://www. hurriyetdailynews.com/syria-armenians-move-to-nagorno-karabakh-azerbaijan-55588.

${ }^{35}$ See, eg, 'EU Local Statement on the Secretary General's 15th Consolidated Report on the Conflict in Georgia', 19 April 2017, https://eeas.europa.eu/delegations/council-europe/24837/eu-local-statement-secretary-general\% E2\%80\%99s-15th-consolidated-report-conflict-georgia_en.

${ }^{36}$ Ellen Berry, 'Abkhazia Lures Its Expatriates, Welcoming Them One by One', The New York Times, 7 May 2009.

37 'Living in Limbo: Rights of Ethnic Georgian Returnees to the Gali District of Abkhazia', Human Rights Watch, 15 July 2011, https://www.hrw.org/report/2011/07/15/living-limbo/rights-ethnic-georgians-returnees-gali-districtabkhazia (noting that the occupation policies 'could force large numbers of Abkhazia's ethnic Georgians to
} 
established an official government entity, the State Committee for Repatriation, which encourages ethnic Abkhaz from the diaspora to move to the occupied territory. It actively recruits such individuals, and organises their flights and transportation. ${ }^{38}$ The authorities also provide them with free housing, subsidies, and other assistance. ${ }^{39}$ Significant sums are invested in construction for the settlers. ${ }^{40}$ In 2013 the Abkhaz State Committee for Repatriation authorities reported that over 7,300 ethnic Abkhaz settlers had come to the occupied territory during the past two decades. ${ }^{41}$ The number seems small until considered against the backdrop of local demographics. While precise numbers are disputed, there are roughly 180,000 inhabitants of the territory, a slight majority of them Abkhazi. Thus the settlers represent over 4 per cent of the population, and an even greater share of the non-Georgian people. A particular focus of the settlement efforts has been ethnic Abkhazi refugees, ${ }^{42}$ who are taken in from conflict zones such as Syria. ${ }^{43}$ These refugees are brought in to settle in the area under a 'law of return'style policy. So far, there have been no protests against these actions by the international community.

\section{Conclusion}

International practice strongly suggests that the settlement of refugees in occupied territory does not violate Article 49(6) of the Fourth Geneva Convention, even when such refugees have an ethnic or national affiliation with the occupying power. As a textual matter, this could be because refugee resettlement does not constitute 'deportation or transfer'. In several of these cases, the refugees had come from third countries or had recently taken shelter in the territory of the

leave their homes forever'). The extent to which such policies have succeeded is unclear because of the lack of reliable population figures for Abkhazia as a whole, and the Georgian minority in particular: ibid 22. See also 'Human Rights in the Occupied Territories of Georgia', Delegation of Georgia to the Organization for Security and Co-operation in Europe, RC.DEL/186/10, 18 October 2010, 3-4.

${ }^{38}$ As part of the government budget, the settlement programme is financed primarily by Russia: 'The State Repatriation Committee Holds a Meeting on the Issue of Repatriation from Syria', 4 May 2013, http://old. mfaapsny.org/en/information/?ID=1021.

${ }^{39}$ Anaid Gogoryan, 'Abkhazia Looks to Turkey for Fresh Blood', Institute of War and Peace Reporting, 12 November 2010, http://www.refworld.org/docid/4ce247761a.html.

${ }^{40}$ During recent policy discussions regarding preference between construction and buying out of existing realty for the repatriating ethnic Abkhaz, the head of the Abkhaz State Committee for Repatriation stated that the planned 2018 budget of his organisation stands at 158 million rubles: Badrak Avidzba, 'Kvarchia about Buying Accommodations for the Repatriates "Real Property Will Not Become More Expensive"”, 18 December 2017, Sputnik Kavkaza, http://sputnik-abkhazia.ru/repatriation/20171218/1022691758/kvarchiya-o-pokupke-zhilyarepatriantam-nedvizhimost-ne-stanet-dorozhe.html.

41 'Between 1993 and 2013 Republic of Abkhazia State Committee for Repatriation Registered 7,365 People', Apsnypress Abkhaz Republik State Press Agency, 6 August 2013, http://www.apsnypress.info/news/s-1993goda-po-2013-god-goskomitetom-ra-po-repatriatsii-zaregistrirovano-7-365-chelovek.

42 '145 Repatriants from the Syrian Arab Republic are Settled into the Hotel “Aytar” in Sukhum', Abkhaz World, 20 April 2013, http://abkhazworld.com/aw/diaspora/132-145-repatriants-from-the-syrian-arab-republic-are-settledinto-the-hotel-qaytarq-in-sukhum.

${ }^{43}$ Paul Rimple, 'Syrian Refugees Grapple with Adapting to Life in Abkhazia', Eurasianet.org, 26 March 2014, http://www.eurasianet.org/node/68194; The Voice of Russia, 'Abkhazia: Welcoming Refugees from Syria, Unrepresented Nations and Peoples Organization, 1 May 2013, http://unpo.org/article/15849. 
occupying power, thus not constituting part of the 'civilian population' of the occupying power. This could also suggest that the individual right of refugees to safe asylum is not suspended because the territory in which they find such asylum is occupied.

Looking at prolonged occupations and comparing them with the Israeli-Palestinian conflict, it could be difficult to find application because of the lack of implementation of any return proposals after a generation. The Arab-Israeli conflict has produced numerous refugees on both sides. Jewish refugees fled or were expelled from the areas of Mandatory Palestine occupied by Jordan and Egypt, as well as from all of the countries of the Arab Middle East in 1948 and the next two decades. Many of these refugees were accepted by Israel. Some of the refugees from Mandatory Palestine returned to those areas following the end of Jordanian and Egyptian occupation in 1967. Refugees from Arab countries, as well as large numbers of refugees from the Soviet Union in the 1970s and 1990s, were accepted by Israel and took up residence in these areas. International practice in other situations of occupation suggests that the movement of such persons to the West Bank would not be considered a violation of Article 49(6).

\section{DisCUSSION}

A question was put to Professor Goodwin-Gill about the relationship between UNRWA and the Refugee Convention, which is understood as mediating the relationship between the refugee and the host state. Would exempting the Palestinian refugees from such provisions be providing states with certain leeway towards the Palestinian refugees, especially countries such as Lebanon, Syria and Jordan? Professor Goodwin-Gill responded that the three states mentioned were not part of the Refugee Convention in the first place. In fact, the reason Arab countries pushed for such special provision, in the form of UNRWA for the Palestinian refugees, was precisely for continuity and because of the uncertainty about whether countries would sign up to the Refugee Convention. Furthermore, there was a general assumption that the situation would be resolved by 1954. UNRWA and the Refugee Convention were not intended to be interpreted for many modern situations.

Another participant asked specifically regarding the three alternative start dates of the Refugee Convention. If the determining date is 22 April 1954, when the Convention came into force, then refugees who fall outside these dates (meaning they were not considered refugees or were not receiving support from other UN agencies until after those dates) would not be protected under the Convention if they stopped receiving UNRWA support. However, this is not the situation under existing case law. Therefore, what are the mechanisms for including those who started to receive the benefits after the latest of the start dates? Goodwin-Gill again emphasised the ambiguity of the wording in the Convention. While 'persons who are at present receiving from organs or agencies of the United Nations other than the United Nations High Commissioner for Refugees protection or assistance' can be interpreted to include any of those three dates mentioned, it may also be interpreted as 'present day' if the refugee is currently in receipt of protection or assistance.

The participant posed a question regarding Article 1D. A hypothetical example was given of a Palestinian refugee who takes up another citizenship. Under Article 1C(3) of the Convention he 
or she would cease to be a refugee. However, that person continues to require UNRWA assistance. How would courts view this person's status under the Convention's ipso facto clause if UNRWA protection ceases for involuntary reasons? If, for example, the person has Jordanian nationality and had to leave involuntarily for the US, how would Article 1C(3) apply? Professor Goodwin-Gill explained that typically any refugee who acquires a new nationality or has an alternative nationality does not come within the terms of the Refugee Convention for there is a presumption that the person will now enjoy the protection of the new state. There was a case in Scotland where the (Jordanian) nationality of the Palestinian was not effective and the refugee was therefore given protection under Article 1D.

Another participant asked for elaboration of the continuous status of the Palestinian refugee with the descendants of the originally displaced people. Professor Goodwin-Gill explained that the jurisprudence generally accepts - on the basis of the practice of UNRWA, which was endorsed by the General Assembly with the support of numerous resolutions - the provision of further assistance to the descendants of those who were originally displaced. In practice, it was also generally accepted that those descendants should also be treated as Palestinian refugees. Other participants noted that UNRWA has registered the descendants of the original refugees and reported on them to UNHCR on an annual basis since the inception of the agency. Significant discussion of this practice took place in 1959, when it was noted and generally accepted. The UN Secretary-General reported that the General Assembly approved the tacit definition. It is not dissimilar in other protracted situations. For example, most of the Afghan refugees who returned to Afghanistan after 2001 were born in Pakistan, but were given and treated as refugees of Afghanistan. Another important UNHCR document of 2006 regarding Palestinians in Iraq makes a clear statement that the Palestinians in Iraq are to be considered Palestinian refugees even if they enter other countries. This document states, furthermore, that third country resettlements of Palestinian refugees should only be temporary because UNHCR upholds the right of return.

A further example was given for the expansion of the UNHCR Mandate, as adopted in 1950 through various General Assembly resolutions. The UNHCR Mandate not only extends to refugees with a well-founded fear of persecution, but also to other 'persons of concern', who have been understood in practice to refer to asylum seekers, returning refugees, persons displaced by conflicts, or other reasons seriously disturbing to public order.

A participant queried the definition of 'Palestinian refugee', and specifically why it pertains to a person living in Palestine from 1946 to 1948 rather than having been 'born in Palestine'. It was suggested that the definition of a refugee as someone living in Palestine during the period 194648 who lost both his home and livelihood was the operational aspect of UNRWA. In this context it was also said that given UNRWA's mandate and obligations, it is not surprising that descendants are included. For matters of return a different definition might be appropriate. Professor Goodwin-Gill recalled that the right to return is not contingent on refugee status; the Convention itself refers to relevant resolutions.

A question was raised about the connection between the examples of settler refugees in other conflicts and the current Israeli-Palestinian conflict. A participant was interested to know when 
the lines should be drawn - pre-1967 or post-1967? This question about the drawing of lines has been the stumbling block for peace negotiations. Is it possible to resolve the refugee issue without dealing with this question? Professor Kontorovich responded by clarifying the refugee settlers nexus cases to which he had referred. Northern Cyprus and Abkhazia may not be considered a situation of 'settlers' because they were not in the occupied territories. The refugee settlers nexus occurs in situations such as the Soviet-occupied territory in the Baltic states. The analogy between these cases and the current situation in Israel-Palestine may indeed be limited. Furthermore, attempts to resolve the refugee issue with the peace negotiations in the past, such as in the case of Northern Cyprus, have not been successful. Another participant remarked that in all of the cases presented, the settlers were returned to the territory of their state of nationality, and not necessarily the 'occupied territory'. The Vietnamese Cambodian refugees, for example, were later returned to the territory of Cambodia, not necessarily the exact location of their earlier uprooting. Similarly, applying the same thinking to the Israeli-Palestinian conflict, the refugees would be settled in an agreed new sovereign state of Palestine, not necessarily the territories from which they originally came.

\section{SESSION 3: The Right OF RETURN}

\section{Do the 1948 Palestinians Have the Right to Return?}

Professor Yaffa Zilbershats, Chair, Planning and Budgeting Committee, Council of Higher Education

Professor Zilbershats opened by stating that the return of the Palestinian refugees and their descendants to the State of Israel is one of the most difficult issues facing the parties as they seek to resolve the Israeli-Palestinian dispute. According to the Palestinians, the refugees and their descendants have a right to return to the homes that they left during the period 1947-49. In contrast, the State of Israel opposes recognition of the right of return and extensive entry of Palestinian refugees into its territory as part of the resolution of the dispute, as it sees this as an existential danger to the national home in which the Jewish people seek to implement their right of self-determination.

Professor Zilbershats clarified that her goal was to prove that the sources of international law do not support the legal right of the Palestinian refugees to return to the State of Israel. Accordingly, Israel must insist that the issue of the Palestinian refugees be dealt with in the framework of political negotiations. Israel must refrain from discussing this issue within the framework of rights. She said she would also review cases of other refugees in regions around the world where ethnic disputes are under way and show that the return of refugees who are members of one national ethnic group to territory that is controlled by another group is generally not the appropriate solution for ending a prolonged ethnic dispute. 
Many of the country's Arab inhabitants fled, or were deported, as a result of hostilities that erupted in Mandatory Palestine following the UN General Assembly decision on the partition of the territory into two states, Jewish and Arab, ${ }^{44}$ and following the War of Independence of the State of Israel. Many became refugees in the neighbouring Arab states. These refugees were excluded from the application of the Convention relating to the Status of Refugees of $1951^{45}$ and from the protection of UNHCR. Since 1950 they have been protected, by virtue of a UN resolution, within a special framework - namely UNRWA. Over the course of time UNRWA has become an organisation that functions as a major relief agency. It handles approximately 4.7 million people, yet refrains from rehabilitating the refugees. This figure stems from the organisation's broad definition of a Palestinian refugee. The UNRWA definition, unlike the definition given in the Refugee Convention, includes descendants of the refugees who left Mandatory Palestine as well as those who have acquired citizenship in the countries in which they have since settled.

The Palestinians base the refugees' right of return on international law. They refer both to UN resolutions and UN conventions. We believe that neither vests a right of return upon Palestinian refugees. The discourse of rights in this area largely developed following the Second World War. The UN adopted many conventions on human rights and the signatory states undertook to safeguard these rights within their territory. Concurrently, monitoring and supervising mechanisms were established to implement the conventions.

Professor Zilbershats moved on to review various relevant legal sources, the first of which is UN resolutions. The primary resolution upon which the Palestinians base their claim to a right to return is UN General Assembly Resolution 194(III) of 1948. ${ }^{46}$ This Resolution sought to set out a general strategy for resolving the dispute through the establishment of a Conciliation Commission. Indeed, the return of the refugees is mentioned in Article 11 of the Resolution, but this must be seen as part of the general strategy and not as an independent right vested in the Palestinians, particularly as the Resolution does not refer to the term 'right' and, when adopted, was rejected by the Palestinians. Subsequent resolutions of the UN General Assembly recognise the right of the Palestinian people to self-determination and the right of the Palestinians to return to their homes. In contrast, Security Council Resolutions 237 and 242 of $1967^{47}$ and 338 of $1973^{48}$ call for a 'just' solution to the Palestinian problem, but make no reference whatsoever to their 'right to return'. It is these decisions of the Security Council that are binding in the relations between the Israelis and the Palestinians, as the Oslo Agreements signed by the two parties ${ }^{49}$ vest them with binding force following their adoption by the parties.

\footnotetext{
${ }^{44}$ Res 181(II) (n 13).

${ }^{45}$ Refugee Convention (n 19).

${ }^{46}$ Res 194(III) (n 11).

${ }^{47}$ UNSC Res 237 (14 June 1967), UN Doc S/RES/237; UNSC Res 242 (22 November 1967), UN Doc S/RES/ 242.

${ }^{48}$ UNSC Res 338 (22 October 1973), UN Doc S/RES/338.

${ }^{49}$ Declaration of Principles on Interim Self-Government Agreements, 13 October 1993, 32 ILM 1525 (1993) (Oslo Accord I); Israeli-Palestinian Interim Agreement on the West Bank and the Gaza Strip, 28 September 1995, 36 ILM 551 (1995) (Oslo Accord II).
} 
The international human rights conventions do not provide uniform definitions regarding the scope of the right of freedom of movement on which, on occasion, the right to return is allegedly based. One of the important documents pertaining to this subject, relied on by the Palestinians, is the International Covenant on Civil and Political Rights of 1966 (ICCPR). ${ }^{50}$ Article 12(4) of the Covenant prohibits the imposition of arbitrary restrictions on the right of a person to enter his own country. The Palestinian refugees do not satisfy the terms of the article and therefore it too does not vest them with a right to return to the State of Israel. For the Palestinians, Israel is not 'their country', and even if it is regarded as their country, the restriction on their entry is not arbitrary. The State of Israel is entitled to prevent the entry of Palestinians into its territory and, a fortiori, the entry of their descendants, as such a development might endanger the existence of the state and the exercise of the right of the Jewish people to self-determination within it.

Nor do international nationality laws impose a duty on the State of Israel to grant citizenship to Palestinian refugees. The general international conventions, and those dealing specifically with the question of citizenship, provide for the right of every person to citizenship, but there is no express obligation on the part of any state to grant such citizenship. Arrangements for the granting of citizenship to those who leave the state in situations where large movements of people are generated as a result of war that has led to border changes, have not yet been formulated in binding rules, and therefore are not legally binding in the context of the issue of Palestinian refugees.

International refugee law is defined primarily by the Convention relating to the Status of Refugees of 1951. This Convention provides for the right of refugees not to be deported to the country from which they escaped and in which their lives or freedom are in danger. ${ }^{51}$ Global practice over the years testifies to the fact that states have not interpreted this right as indirectly obligating the original state to permit the return of the refugees. Similarly, the Statute of the Office of the UN High Commission for Refugees of $1950^{52}$ provides that return is merely one of the possible ways of resolving refugee issues. Irrespective of the above, the Refugee Convention has excluded the Palestinian refugees from its purview and, in accordance with UN decisions, has made them the responsibility of UNRWA. At the same time, the latter agency has not been tasked with dealing with the return of the Palestinians.

An examination of precedents from around the world relating to the resolution of ethnic disputes in which the fate of many refugees is involved reveals a variety of solutions for dealing with this issue as part of the attempt to resolve or stabilise national disputes. Until the end of the Cold War, the legitimate and even preferred solution for ethnic disputes was the forced exchange of populations. The premise was that such a solution contributed to the stabilisation of the states that were suffering from ethnic tensions. This was the case in relation to the peace agreements between Greece and Bulgaria in 1919 and between Turkey and Greece in

\footnotetext{
${ }^{50}$ International Covenant on Civil and Political Rights (entered into force 23 March 1976) 999 UNTS 171 (ICCPR).

${ }^{51}$ Refugee Convention (n 19).

${ }^{52}$ UNGA Res 428(V) (14 December 1950), UN Doc S/RES/428.
} 
1923. ${ }^{53}$ The Peel Commission of 1937 called for the partition of Mandatory Palestine into two states and recommended the exchange of populations in reliance on the Greek-Turkish precedent. ${ }^{54}$ Similarly, at the time of the partition of India into India and Pakistan in 1947, an exchange of populations involving millions of people was carried out with the aim of separating two disputing ethnic groups.

Thus, when the problem of the Palestinian refugees arose, the exchange of populations, particularly in cases of ethnic disputes, was regarded as a legitimate and even appropriate solution. In retrospect, it is possible to regard the absorption of hundreds of thousands of Jewish refugees from the Arab states in Israel, which took place at the same time as the escape or deportation of Palestinian refugees to the neighbouring Arab states, as such an exchange of populations. The new reality that evolved could have provided a fitting infrastructure for the settlement of the dispute. However, unlike the State of Israel, the Arab states in general did not take measures to absorb the refugees and resettle them, but rather encouraged the continuation of the refugee situation and the aspiration to return to the territory of the State of Israel.

Following the end of the Cold War the process of population exchange was defined as ethnic cleansing and was absolutely prohibited by international law. Return was adopted by states, particularly by those that absorbed refugees, as the preferred solution for the problems of refugees which had been created by ethnic disputes. However, in many cases this policy encountered difficulties and sometimes was not capable of being implemented at all. This, for example, was the situation in Bosnia and Herzegovina, which had formed part of the former Yugoslavia. The war in the region gave rise to an increased movement of refugees. The Dayton Agreement of 1995 provided for their right to return to their homes. ${ }^{55}$ In practice, the return of these refugees has encountered numerous obstacles, including ethnic hostility, which to this day still on occasion turns into severe violence.

In Cyprus, the Secretary General of the UN, Kofi Annan, proposed in 2004 to the populations in the two sections of the island to resolve the refugee problem that had been created about thirty years earlier. His proposal included a minimal return of refugees, so that each ethnic community could remain a majority in its own territory. ${ }^{56}$ This example shows that the international community concurs that even now a legitimate solution to an ethnic dispute that resulted in many refugees will not necessarily include the extensive return of refugees to their original place of residence. According to Professor Zilbershats this view is supported by the Demopoulos judgment of the European Court of Human Rights, which in March 2010 decided the issue of the property rights of Greek Cypriots who had lived in Northern Cyprus and moved to the south of the island following the Turkish occupation. The Court stated: ${ }^{57}$

\footnotetext{
${ }^{53}$ Convention between Greece and Bulgaria respecting Reciprocal Emigration (27 November 1919) 1 LNTS 67; Convention concerning the Exchange of Greek and Turkish Populations (1 May 1923).

${ }^{54}$ Peel Commission (n 3) 390.

${ }^{55}$ General Framework Agreement for Peace in Bosnia and Herzegovina (14 December 1995) Annex 7 (Dayton Agreement), art 1.

${ }^{56}$ Annan Plan (n 25).

${ }^{57}$ ECtHR, Demopoulos v Turkey, App no 46113/99, 1 March 2010, paras 84-85.
} 
The considerable amount of time, which had elapsed since the creation of a refugee problem, has a significant impact on the manner in which the Court interpreted and implemented the provisions of the rights to property, respect to home and prohibition against discrimination, provided in the Convention and the Protocols.

The judges pointed out that during the 35 years that had elapsed since the events of 1974, which caused the problem and forced the petitioners to leave their homes, generations had passed, and the local population had changed. Turkish Cypriots who had come from the south of the island were now settled in the north. Turks who had come from Turkey had also settled in the north of the island. A considerable portion of the property of the Greek Cypriots had changed ownership through donations, sale or inheritance. The lapse of time had therefore weakened the links between those who claimed rights in the property and the property itself. This had implications for the nature of the remedy to be regarded as meeting the conditions of the Convention: when restoration of the property was not possible, compensation would be regarded as appropriate.

The Court not only examined the violations of the rights of the petitioners but also asked whether the right to property and the expectation of enjoying the full benefit issuing from it was consistent with actual reality. In view of this reality, was it appropriate to allow the petitioners to exercise their rights? The judgment upheld the argument put forward by the Turkish-Cypriot government and stated that it would be arbitrary, dangerous and unreasonable after 35 years to expect the Court to order the unconditional restoration of the petitioners' property. A state was entitled to take into account additional factors, including the status of additional parties who had occupied many of the assets for many years. If the Court had ordered the unconditional return of the property, this would have disregarded the rights of those now living there, or those making essential use of the property for public purposes. Accordingly, the Court emphasised that it was not interpreting the Convention in such a manner as to impose a sweeping and unqualified obligation on the government to forcibly remove and expel the inhabitants in order to resettle those who asserted a right to the property, even if this would protect the rights of the petitioners as entrenched in the Convention. ${ }^{58}$

Professor Zilbershats concluded by saying that it is recommended that the discussion on return be shifted from the discourse of rights to the domain of political negotiations. The State of Israel should not be tempted to recognise the right of return of the refugees by a proposed guarantee or understanding to the effect that such recognition will not result in de facto return. Israel should not be misled into thinking that recognition of the right is only a symbolic gesture aimed at acknowledging the suffering of the refugees. The alleged right may have far more than symbolic significance: it may be the right of individual refugees, and it is not at all clear that the Palestinian representatives are entitled to waive such rights. Indeed, the claim that this right cannot be waived is made expressly by those who assert it. Professor Zilbershats clarified that if the view is taken that the refugees have a right to return, the leaders may not be able to forgo that right during negotiations. The sweeping solution of return is incompatible with the interests

\footnotetext{
58 ibid para 116 .
} 
and the rights of the State of Israel as the state of the Jewish people. Of course, it is important to bring an end to the suffering of the Palestinian refugees. Yet, extensive return to the State of Israel of a population with cultural and social characteristics - which differ so sharply from those of the Jewish population, when there is such deep hostility between the two groups - is certainly neither the correct solution to the suffering of the refugees, nor the way in which to achieve stability in the region.

\section{Palestinian Refugees, the Right of Return and Israeli Legal Practice}

\section{Advocate Manal Hazzan}

Advocate Hazzan began by stating the Palestinian claims: namely a just solution within the framework of international law, including UN General Assembly Resolution 194(III)). This means the right of return and reparations. The Palestinians suggest four solutions for geographical locations to implement the return: the State of Israel, the future Palestinian state, both states, or third-party states.

The status of the refugees in Arab countries differs between countries, and their description given earlier as poor and downtrodden is inaccurate. In Lebanon the situation is indeed very bad, but in Syria, until the civil war, and in Jordan they have acquired rights, such as the right to vote.

Advocate Hazzan said that Israel's position is not based on a legal framework but on a moral rejection and denial of responsibility for the refugee problem. The denial in Israeli practices is not only within the territory of the State of Israel but also in the West Bank. The refugee issue should not be viewed as an isolated issue, but one within the wider context of Israeli laws on status and citizenship. At its core is the issue of demography. This leads to the absence of a notion of citizenship. The Palestinians view the Israeli policies as an ongoing Nakba.

Since 1967 Palestinians in West Jerusalem have not been granted citizenship and there are limitations on their ability to transfer status to descendants. They cannot leave the area for fear of loss of status. The family reunification legislation also incorporated considerations of preventing return. These temporary measures have become permanent. There are 10,000 stateless children as a result of these laws. So, when Israel speaks of the vast numbers and of the responsibility of Arab states and maybe UNRWA for the problem, Israel by its own laws is contributing to the numbers of stateless people and refugees in future generations.

Palestinians in the West Bank need Israel's permission to leave the territory, which means that Israel controls their movement. The implications for this kind of control is more stateless people. Tens of thousands of stateless people do not fall within the definition of refugee or UNRWA protection. They remain entirely without protection.

The status of Israeli Palestinians and their situation cannot be explained by an existential threat; these are Israeli nationals. The explanation for their status is based on interests in land.

In recent years Israel has restricted the entry of foreigners to the West Bank. They are treated as refugees exercising the right of return. At issue are people with ties in the West Bank who come for family visits, or to remain, or to volunteer. The maximum for which they can stay is 27 months. 
Advocate Hazzan said that apart from creating more instances of statelessness and refuge, from Israel's practices within its own territory, there are also attacks on refugees. She spoke not of attacks in Gaza, where the population consists mostly of refugees, but of attacks on aid agencies assisting refugees, such as UNRWA. The UN Office for the Coordination of Humanitarian Affairs (OCHA) has issued a report on attacks on humanitarian aid agencies. ${ }^{59}$

She concluded by saying that Israeli practices in East Jerusalem with respect to the internally displaced in Israel and in the West Bank, through regulation, aid and population registration, indicate that at issue is not only sovereignty and international law, but politics. It is not about security but about ethnic cleansing.

\section{Discussion}

Questions were raised about the comparison between Arab and Jewish refugees, and the claim that the Zionists brought the Jewish refugees here to support the Zionist cause and therefore there was no room for comparison. Professor Zilbershats agreed that there were differences, but maintained that legally there should not be a difference as both groups were refugees.

A participant reverted to the political ramifications of acknowledging the right to return, and raised the possibility of acknowledging return not as a right but as a price that Israel may be willing to pay for reaching an agreement.

Another participant opined that the analogy between Palestinian and Jewish refugees was factually flawed given the circumstances of each group's departure. In addition, the other examples given by Professor Zilbershats concern resettlement in the refugee's own state. There is no state of Palestine, and one probably cannot resettle six million in the West Bank. Professor Zilbershats agreed that the question whether Jews fled from the Arab states, were brought to Israel, deported, and so on should be set aside, as all are probably correct to some extent. She said that if the Arab states had agreed to full return, Jewish refugees should not go back with full rights. Similarly, she opposed the search for Jewish property in Europe. The Cyprus case indicates that property rights need not be exhausted. It is not the right against torture or the right to life: it is property. It should be protected against the state, but life goes on. To continue to pursue it eventually causes suffering to the other side.

Another participant maintained that the right of return is stronger than is contended by Israel (and Professor Zilbershats). There was more legal prohibition on forced displacement in the 1940 s, even if state practice is different. As a matter of international law, the right of return is more firmly established than has been stated here. The UNHCR Handbook is very clear on this. At the same time, it is not as strong as the Palestinians claim. It is also quite fuzzy: where will the place of return be? At what time does the right begin to fade? There is an issue of political feasibility. Israel cannot be expected to sign up to an abstract right to return

\footnotetext{
${ }^{59}$ Abby Stoddard, Adele Harmer and Katherine Haver, 'Safety and Security for National Humanitarian Workers Annex 1: To Stay and Deliver', Office for the Coordination of Humanitarian Affairs Policy Development and Studies Branch, 2011.
} 
without practical guarantees of what it includes. At the same time, given that Israel's existence includes the notion of return, there is a problem in arguing that the Palestinians' right runs out after a few decades while the Jewish right ran for 2,000 years. As for numbers, it is not expected that six million Palestinians will return, but the Palestinians insist on a principled position as a point of departure. How can these positions be massaged to fit together? All negotiations have been on the idea of compromise on a right of return to the West Bank. The refusal to address normative concerns makes a compromise unfeasible.

The significance of the Demopolous case was queried by another participant. It is not clear whether it indicates that the right has weakened significantly, or that it was not there in the first place. The participant also queried to what extent the present case is unique in that mass return is seen not only as a security threat but also a demographic problem.

Another participant emphasised that symmetry requires that every person who was forced to leave should be entitled to return, but the issue of Palestinians is not a post-conflict situation and there is no symmetry. The side in control cannot demand symmetry; it bears more responsibility. The deportations of Arab Jews and bringing them to Israel served for Israel the same goal as ethnically cleansing Palestinians from Palestine.

A participant highlighted the need to address the narrative of the other side. Some of the resolutions refer to the right of return as inalienable. As for the ICCPR, Israel's position is that the right of return is guaranteed on an individual basis, but in the participant's view, a person's 'country' should also be the country of residence. As for absorption of Jewish refugees, the participant considered this to be more of a social, political or moral issue. There is a connection between the plight of Jews and of Palestinians. If we take 1948 as the constituent moment for these people, they are historically linked, but Israel is trying to link them in bilateral negotiations, offering to compensate but deduct what the Arab states owe the Jews. The most important lesson from the Demopoulos case is not that it focused on a property exchange but that the Court took account of the passage of time, when only a few years earlier the Dayton Agreement had been signed, which provided for a return of refugees. The Court needed to distinguish between the two cases. This does not mean that there is no right, but only that there are other rights that need to be reconciled. Israel understands profoundly what the right of return means. It is not a matter of a large number of individuals. This is a people returning to its land to reconstitute itself as a nation. This is fundamentally the core of the conflict. Only after accepting a two-state solution will that be possible.

Professor Zilbershats concurred that demography is a strong consideration. It constitutes part of the creation of what is the right of return of Jews, meaning that there is also a right of selfdetermination. There was concern that the law on reunification was actually about demography. This should be acknowledged openly. Advocate Hazzan emphasised the political character of the demographic issue and queried whether the right of self-determination is ongoing, even when there is already a state.

One participant noted that return has been the preferred solution from the 1920s. Admittedly there are grey areas but that does not mean that the state has absolute discretion. International law provides a framework for solutions, as long as the law remains connected to a sense of justice. 
The participant asked Professor Zilbershats how to integrate the right to self-determination, of which she approved, in light of the Palestinian people's situation, especially in relation to territory. Professor Zilbershats responded that if there is a Palestinian state, it will resolve the right of return issue. Politically the Palestinian state is not happening, but legally that is the route.

Another participant said that Article 12(4) of the ICCPR refers to a person's 'own country' and not 'own state'. It is a geographical rather than a political definition. Furthermore, a decision against a specific individual is arbitrary. Let us assume that a person lived here until 1948 and then left, regardless of whether as a result of expulsion or otherwise. To refuse that person the right to return on the ground that thousands of others are denied the right is arbitrary, as is to deny them so that not everyone will have the right. Also, if Israel agrees with the Palestinian Liberation Organization (PLO) on a return to a Palestinian state in the West Bank and the Security Council adopts a resolution which states that this agreement exhausts all UN resolutions, why would this right persist on an individual basis? Professor Zilbershats conceded that it was difficult to draw the line between individual and collective rights.

\section{SEssion 4: Restitution and Compensation}

\section{Restitution AND Compensation}

Professor Rex Brynen, Department of Political Science, McGill University

Professor Brynen made some introductory remarks. First, the notion that property seized would be returned is very unlikely for political reasons. With regard to terminology, 'reparations' might be a more accurate term but it is politically loaded because of its Second World War connotation. Therefore, he would use the term 'compensation'. In every set of negotiations between Palestinians and Israel the topic of compensation arises, and both sides assume that compensation will be part of the settlement. Evaluation of the compensation payable can go anywhere from four billion to four hundred billion dollars. One can talk about a narrow range (limited to property losses) or an expansive package. The Israelis would like to know the number in advance, and do not want a process to calculate the amount. The Palestinian position is that they do not know the precise figure, so there should first be agreement that there will be compensation and then the Israelis will pay. It is assumed that the international community will foot the bill, but many in the international community refuse to do so, demanding that Israel pays. Israel has always contemplated numbers in the low billions, which is considerably low and is unlikely to satisfy the Palestinians. In addition, Professor Brynen noted that the Israelis always bring up the issue of Palestinian and Arab responsibility for rejecting the Partition Plan, and so on.

Another issue is to whom Israel should pay - whether it is individual persons, families, or perhaps the Palestinian Authority (regarding which concerns were raised on grounds of a lack of legitimacy). There is a real risk that a deal would be forged by political concerns that would not be feasible in practice. 
A claims-based system is the Palestinian preference, because it is a form of acknowledgement that Israel had displaced them. It is a problematic mechanism because the system is very slow and time-consuming, as descendants live in various countries with different inheritance laws. Moreover, compensating on the basis of property owned before 1948 could be problematic because it will result in giving a large share of the compensation to the rich families who have always been rich, and those in refugee camps would receive much less because the distribution of resources before 1948 had never been equal.

The host countries also demand a right of compensation for hosting the Palestinian refugees, but the general approach of the international community is to reject their demands. The Jordanian government, for example, is demanding compensation or a package for supporting a deal. Palestinians in Jordan are better off than the average Jordanian, but in Lebanon they are treated terribly. In addition, the deal should not require the refugees to make an immediate decision, but give them time to decide.

Another issue is how to move forward in practice. Should the parties defer working on the modalities and just agree on a framework agreement? Or should they agree on the modalities from the beginning, which could cause problems in negotiations?

On the Israeli side, there is a way to reduce the bill by linking Jewish refugees to Palestinian refugees. This is a problematic position because it does not seem morally just that a Palestinian refugee should lose out for something he or she did not do, and not make, say, the Iraqi or Egyptian government responsible. It would also reduce the amount of money the refugees would receive, and that would be counterproductive politically.

Professor Brynen concluded by saying that he thinks that inadequate attention has been given to the compensation issue. Research in social psychology shows that if you take an issue that is dear to someone and tell them to compromise and accept money instead, it makes them less willing to compromise if the deep normative issues involved are not also addressed. In short, just throwing money at the problem does not solve it. Israel needs to acknowledge its wrongdoings, which may be just as important to Palestinians as money. This is what Professor Brynen advised the US State Department during John Kerry's term.

The issue of who should represent the Palestinians was raised. On the one hand, there is the Palestinian Authority, which lacks legitimacy in the eyes of many Palestinians. On the other hand, Professor Brynen has his doubts that grassroots movements would be effective at the negotiating table.

\section{Unequal Property Rights: Restitution in IsRaeli LaW}

\section{Advocate Alaa Mahajna}

Advocate Mahajna said he would focus his argument on restitution under Israeli law. He would use Jerusalem as a case study to show the differential application of the law relating to restitution, based on a policy and practice grounded on ethnicity, nationality or religion, which aims to maximise Jewish ownership and control over land, especially in East Jerusalem, and a policy of dispossession of Palestinians (in East and West Jerusalem). 
Advocate Mahajna introduced three current examples from three Palestinian villages inside Jerusalem: (i) Sheik Jarrah, a Palestinian neighbourhood in East Jerusalem; (ii) Batn al-Hawa, located in Silwan in East Jerusalem; and (iii) Liftah, a village at the entrance to Jerusalem in the south, displaced in 1948.

Sheik Jarrah is a neighbourhood located between the Old City and Mount Scopus. Since the 1970s many Palestinian families living there have been under the threat of eviction. They were settled there by UNWRA and the Jordanian government in houses of Jews who had fled during the war. The Palestinian families were promised property deeds by the Jordanian government but never received them. After the war in 1967 two settler organisations demanded the properties back in the form of restitution. The court claimed that these organisations did not have sufficient evidence for their claims. In 1982 the court upheld their claim, but said that the Palestinian residents were 'protected tenants' and therefore could pay rent to the Jewish owners. The organisation started a process of eviction on the ground of non-payment of rent and illegal construction. As a result, some families were evicted. Essentially the court held that land that was owned by Jews before 1948 could be subject to restitution. The court did not take into consideration changes in the assets, improvements or occupancy over many years (since 1956), although it did consider the 'protected tenants'.

In Batn al-Hawa in Silwan most residents are Palestinians. In 2001 Ateret Cohanim, an extreme aggressive settler organisation, approached the District Court of Jerusalem and took over a waqf that was created in 1850 for the benefit of impoverished Jewish residents of Jerusalem and poor people in general, including non-Jews. The original mutawalis (trustees) were the two Chief Rabbis. Ateret Cohanim persuaded the court to appoint them as mutawalis instead of the Chief Rabbis (who did not object to this appointment). They then approached the General Custodian who had inherited the administration of the properties from the Jordanian government. The General Custodian released the property to Ateret Cohanim. This was in effect restitution of property to the current mutawalis, the settler organisation, which in 2015 initiated eviction proceedings against tens of Palestinian families living in Silwan. These families were not part of the release procedure, and knew nothing about the release until they were served with the eviction claims. One eviction claim was accepted by the court, which confirmed the ownership; this decision was confirmed by the Supreme Court.

The Liftah case shows that restitution is not possible in relation to Palestinians who demand the return of land, even if they have Israeli citizenship. Their property was confiscated through the Absentee Property Law of 1950 and handed over to the General Custodian, who in turn handed it over to the development authority, which should have used it for the benefit of the public. As part of this arrangement vast tracts of refugee land were sold. The original owners, according to the Law, have lost their ownership forever unless they can prove they were not 'absentees'. Liftawis were deemed to be absentees because they had moved a few kilometres to the east, under Jordanian control, until 1967. The planning authorities sold the land mainly to wealthy American Jews. The village of Liftah is a unique case. In most cases where Palestinians were expelled in 1948, the villages were destroyed and the land used for building houses for Jewish immigrants or used as parks and forests. However, many of the houses in Liftah still stand in the village, and 
most are vacant. It is even considered to be a location with very high architectural value because it shows the Palestinian village as it was in 1948; many architects, in fact, have protested against attempts to demolish the houses because of this architectural value. Currently the planning authorities are advancing a new plan to designate Liftah as a site for luxury housing to be sold mainly to wealthy American and other foreign Jews.

With regard to property seized under the Absentee Property Law, all cases for restitution by Palestinian owners who still live in the area of historic Palestine fail unless the owners can prove that in 1948 they were not 'absentees' according to Israeli law. Even those who acquired Israeli residence or citizenship after 1967 are barred from claiming restitution of this property. This is the case for Liftah and all refugee property, and even for Palestinians who were internally displaced in 1948 but stayed in what became Israel and became its citizens.

To conclude, Advocate Mahajna emphasised that the Israeli legal system disregards Palestinian claims for restitution but allows Jews to claim restitution. The courts and academics rely on the Absentee Property Law and technical excuses to justify this, but the Law violates international norms and human rights. The Jewish state gives more rights to Jews than to other citizens, and tries to help the settlers advance their agendas, while the Law is a tool to eliminate Palestinian presence in certain areas.

The approach of the Israeli legal system raises questions of how the legal system approaches human rights issues and the rule of law, and the differential application of the law. Restitution in Jerusalem is only one example that demonstrates the general trend, whether in the West Bank or East Jerusalem, or even Israel itself. While this situation is inconsistent with international law and is based on racial discrimination, it is not surprising. The State defines itself constitutionally as a Jewish State and it is accepted that, as such, it bestows privileges on Jews, and unequal restitution is part of these privileges. The legal system of the Jewish state operates to facilitate and uphold Jewish privileges.

\section{Discussion}

Responding to questions, Professor Brynen clarified that there should not be a connection between a right to compensation and being registered under UNRWA. The right to compensation for specific property would remain even without registration as refugees.

Another question was whether compensation should be payable for loss of property or for resettlement, which is need-based rather than property-based. Professor Brynen said that there are different views on this matter, and those differences explain the divergent sums of money mentioned. The lower sum assumes that compensation is for loss of property with no inflation taken into account; the higher values represent compensation for lost income with inflation taken into account. In addition, whether to compensate for return or non-return depends on the refugee experience. Professor Brynen prefers a system that compensates for the refugee experience rather than specific losses because such a system is easier to manage, more refugees receive more resources, and there is an element of corrective justice. For Israel the normative implications of such a system are harder. 
It was queried whether any claims have been submitted by Palestinians for property in West Jerusalem. Advocate Mahajna said that the Absentee Law precludes any such claim. Another participant recalled that the owners of the Belgian consulate in East Jerusalem claimed that they were not absentees because they had left the territory for business reasons and had not fled because of the war; they received compensation.

Professor Brynen said that he did not speak of restitution, not because it is not legally possible but because there are legal issues, such as those mentioned by Advocate Mahajna, which reflect a political reality in which restitution is doomed to fail from the start. If Israelis know they might lose their home to a Palestinian, they would refuse to engage in any negotiated deal.

Responding to other questions, Professor Brynen said that he regarded compensation for host states to be less of a priority. The host states argue that they are also entitled to compensation. The Jordanians have raised this to an art, using the same argument with regard to other wars during which they received refugees. The general view of the international community is that it is preferable not to embark on compensating host states because that would be the thin end of the wedge. Nonetheless, it is envisaged that there will be generous support for host states. The general thrust is to distinguish compensation from the issue of the final place of residence, and to consider compensation on the basis of material or more general losses regardless of choice of residence. Many Palestinians regard compensation to Israeli settlers as a standard. They have high expectations, but they will have to settle for less. There is also the secondary problem that the PLO is overselling what it is likely to receive from any agreement.

Another participant raised the issue of who would make the decision on behalf of the individual. It has to be a representative body, but individuals might object to a formal statement of acknowledgement because that would generate a lower form of compensation. There is a problem in squaring the individual claim with the inevitable need for a collective determination.

Another query was whether the issue of Palestinian responsibility had ever been raised. Professor Brynen replied that negotiations in Taba had started with the narrative, but this became so frustrating that the parties went back to technicalities. Nonetheless, addressing the narrative is unavoidable. Another participant highlighted the fact that there is much work on searching for a solution but nothing with a proposal for a narrative. Participants disagreed on the description of events with respect to Palestinian rejection and Israeli consent to proposed solutions.

It was also suggested that the international community might have a responsibility to compensate, given UN involvement in the British Mandate and the persecution of Jews. Professor Brynen noted that, other than the US, states have been reluctant to compensate, arguing that Israel holds the property. This does not mean that the international community will be mean in helping the Palestinian state in its development.

With respect to grassroots engagement, Professor Brynen held that it risks raising demands that are not feasible. Another participant contended that without such engagement, the Israeli concern that the deal does not hold is justified. Professor Brynen maintained that success depends on the whole deal. In his view, the relevant constituency is the local one. Palestinians outside the immediate region (in Lebanon and elsewhere) should not have the right of veto. 
Participants then discussed the status of Palestinians in Jordan. One noted that this status is vague - the Palestinians sometimes being regarded as citizens, and sometimes as refugees who will eventually return to their homes. It was said that this ambiguity was crucial for the kingdom, which wants Palestinians to leave but their money to stay. Another participant challenged the notion of separability between Palestinians and Jordanians in Jordan. After so much time, the communities are interconnected; the people see themselves as part of Jordan.

\section{Session 5: The United Nations Relief and Works Agency for Palestine Refugees in the Near East (UNRWA)}

\section{UNRWA at 66: Between Light and Shadows}

\section{Dr Lex Takkenberg, UNRWA}

Dr Takkenberg began by introducing the origins of UNRWA. It was created upon the initiative of the UN Conciliation Commission for Palestine - comprising the US, France and Turkey - and modelled on the Tennessee Valley Authority. Its founders aimed to expand the quest for a solution to the plight of the more than 700,000 Palestinian refugees unable to return, through economic integration by means of large-scale public work schemes - hence the 'works' in the name. As such, the agency has been an instrument through which the international community has discharged some of its responsibilities towards the communities, countries and territories affected by the events of 1948. Despite the constant reiteration of its temporary nature, the tragedy of the Palestine refugees and the lack of success on the part of the international community in resolving their plight have meant that UNRWA has become embedded in the diplomatic, humanitarian and political architecture of the Middle East.

\section{Some Basics}

Describing the modus operandi of UNRWA, Dr Takkenberg noted that the agency is a subsidiary organ of the UN General Assembly, established by UN General Assembly Resolution 302(IV) of 8 December $1949^{60}$ to carry out direct relief and works programmes for Palestine refugees. The agency reports directly to the General Assembly (the only UN body to do so other than the UN Institute for Disarmament Research). The agency began operations in May 1950, taking over from the international non-governmental organisations (NGOs) that had initially provided humanitarian assistance to the refugees. The agency's mission is to assist Palestine refugees in achieving their full potential in human development until a durable and just solution is found for the refugee issue. It fulfils its humanitarian and human development mandate by providing protection and essential services to Palestine refugees in Gaza, the West Bank, Jordan,

${ }^{60}$ UNGA Res 302(IV), Assistance to Palestine Refugees (8 December 1949), UN Doc A/RES/302(IV). 
Lebanon and the Syrian Arab Republic. UNRWA operated within Israel until 1952. Like most other UN funds, programmes and agencies, UNRWA is funded almost entirely by voluntary contributions of UN member states and the European Union.

Nearly one third of the registered Palestine refugees live in 58 recognised Palestine refugee camps in UNRWA's five areas of operation. Others live outside the camps, often in villages and towns surrounding the camps. The agency does not own, administer or police the camps, this being the responsibility of the host authorities. The role of UNRWA in the camps is limited to providing services and administering its installations, even though the agency may provide assistance with infrastructure and camp improvements to meet the needs of the refugees. While most of UNRWA's installations, such as schools and health centres, are located in the camps, a number are outside. All of the agency's services are available to registered Palestine refugees, including those who do not live in camps.

UNRWA serves Palestine refugees, who are '[p]ersons whose normal place of residence was Palestine during the period of 1 June 1946 to 15 May 1948, and who lost both home and means of livelihood as a result of the 1948 conflict'. ${ }^{61}$ Reference to the period 1 June 1946 to 15 May 1948 was introduced in the definition for the purposes of eliminating from the UNRWA registration records persons with host country nationality who were in Palestine only temporarily at the time of the 1948 conflict. Refugees who meet this definition, as well as their descendants through the male line, may receive UNRWA services if they are living in its area of operations and are registered with the agency. Initially a working definition, the General Assembly has tacitly approved the operational definition of 'Palestine refugee' used in Annual Reports of the Commissioner-General setting out the definition. The SecretaryGeneral (Dag Hammarskjöld) recalled in a report in 1959 that 'UNRWA's working definition of a person eligible for its services ... is not contained in any resolution of the General Assembly but has been stated in Annual Reports of the Director and tacitly approved by the Assembly'. ${ }^{62}$

UNRWA's mandate is not only to provide essential services; it extends also to the protection of Palestine refugees, which the agency understands to mean safeguard and advance the rights of Palestine refugees under international law. The protection activities of UNRWA are firmly grounded in relevant UN General Assembly resolutions, referring to the UNRWA protection mandate, and the agency has strengthened its capacity to address protection issues over time, in particular during the past 25 years.

During its 66 years of existence, UNRWA has undergone extensive reform in response to operational challenges and evolving refugee needs, and has sought to remain abreast of emerging international practices. During the past decade, the agency has undertaken a number of major reforms to organisational processes as well as its programmes.

${ }^{61}$ UNRWA, 'The United Nations and Palestinians Refugees', 1 January 2007, 5.

${ }^{62}$ Proposals for the Continuation of United Nations Assistance to Palestine Refugees (15 June 1959), UN Doc A/4121, Pt II, para 4. 


\section{What Does UNRWA Do?}

After the failure of initial attempts at large-scale economic development, since the mid-1950s UNRWA's mandate has shifted from continuing emergency assistance formerly provided by its predecessor agencies - food, shelter, clothing, and basic health care - to more comprehensive support in meeting the basic needs of the Palestine refugee population pending a just and durable solution. Education rapidly replaced relief as the central programme, with the agency establishing a strategic partnership with UNESCO, relying on the host country curriculum to ensure continuity of education beyond UNRWA's education programme, and successfully introducing vocational training in addition to its basic education programme. A similar partnership with the World Health Organization formed the basis for the agency's health programme.

The pioneering human development strategy of UNRWA proved successful: as the refugees gradually attained self-sufficiency, dependence on direct relief dropped so drastically that by the mid-1980s UNRWA was able to replace its general ration programme with a far more selective programme targeting the poor. Before the recent blockade and conflict in Gaza and Syria, dependence on direct relief assistance had reduced dramatically from nearly 100 per cent at UNRWA's inception to 6 per cent at the turn of the century.

Some 1.75 million pupils have graduated from UNRWA's basic nine-year education cycle, paving the way to economic self-sufficiency for the vast majority of the refugees. Literacy rates among Palestine refugees compare well with regional and global levels, and enrolment statistics have revealed gender equality since the 1960s. At present the agency operates approximately 700 schools with an enrolment of nearly 500,000 children. More than 70,000 students have graduated from technical and vocational training programmes offered by the agency's ten vocational and technical training centres, since the introduction of technical and vocational education and training.

The agency's 143 health centres provide nine million health consultations annually.

The outbreak of the first intifadah in 1987 and subsequent regional developments provided a push for a number of programmatic innovations, introduced from the early 1990s onwards. This included the introduction of a highly successful microfinance programme which, since its establishment, has issued over 420,000 loans totalling more than USD 460 million, making it the largest non-bank financial intermediary in the region.

Another innovation introduced since the turn of the century relates to a more sustained and systemic effort to improve the physical infrastructure inside refugee camps to the extent there are immediate needs that are not otherwise addressed. This includes not only the rehabilitation of a large number of refugee shelters, but also the development and piloting of a participatory camp improvement methodology that is gradually rolled out throughout the agency's areas of operation.

UNRWA has demonstrated repeatedly its ability to respond in a timely and appropriate manner to recurring emergencies. It is currently providing emergency assistance on top of its regular programming to Palestine refugees in and from Syria, to Palestine refugees in Gaza and, to a lesser extent, in the West Bank. In Gaza, for example, with the land, air and sea blockade which has 
continued for more than a decade, the Palestine refugee population is highly dependent on UNRWA beyond its regular services. With opportunities for employment stifled by the blockade - the unemployment rate remains among the highest rates worldwide - almost one million Palestine refugees are dependent on food assistance, up from fewer than 100,000 in 2000. In 2014, 47 per cent of households in Gaza were food insecure, an increase of 45 per cent from 2013 levels.

\section{The Relationship with Host Governments and IsRael}

As a UN agency, the relationship between UNRWA and host authorities is governed by the UN Charter and the 1946 Convention on the Privileges and Immunities of the United Nations. ${ }^{63}$ The agency also has agreements with host authorities in all of its five fields of operation, which set out the cooperation between host governments and the agency (Syria, 1948; Jordan, 1951; Lebanon, 1954; the PLO, 1994; and the Palestinian Authority, 1996). Israel voted in favour of UN General Assembly Resolution 302(IV) ${ }^{64}$ and earlier during the Six-Day War had requested UNRWA to continue its operations in Gaza and the West Bank, with the modus operandi laid down in the Comay-Michelmore agreement of June $1967 .{ }^{65}$ There has been good cooperation with Israel at all levels, from the operational in the field to the political.

UNRWA operations are governed exclusively by the mandate the agency has from its parent organ, the General Assembly. In implementing its mandate, the agency adheres to the four humanitarian principles adopted by the General Assembly, including the principles of neutrality, impartiality and operational independence.

\section{UNRWA AND UNHCR}

Both agencies were established during the same week in December 1949; both were initially mandated to deal with specific groups of refugees; UNHCR only much later became the global refugee agency. Although both deal with refugees and hence are 'sister agencies', UNRWA and UNHCR work to distinct mandates, operational and legal definitions, areas of operation, operational realities and constitutive instruments. At the same time, both are guided by a number of key principles of international refugee protection. There is close cooperation between the two agencies to guarantee 'continuity of assistance and protection' for Palestine refugees wherever they are. Palestine refugees registered by UNRWA, who find themselves outside the agency's area of operation and are unable to avail themselves of the agency's assistance or protection (for reasons beyond their volition or control), fall within the inclusionary aspect of Article 1D of the Refugee Convention, as discussed earlier by Professor Goodwin-Gill.

\footnotetext{
${ }^{63}$ Charter of the United Nations (entered into force 24 October 1945) 1 UNTS XVI; Convention on the Privileges and Immunities of the United Nations (entered into force 13 February 1946) 1 UNTS 15.

${ }^{64} \mathrm{n} 60$.

${ }^{65}$ Exchange of Letters constituting a Provisional Agreement between the United Nations Relief and Works Agency for Palestine Refugees in the Near East and Israel concerning Assistance to Palestine Refugees (entered into force 14 June 1967) 620 UNTS 183.
} 


\section{Challenges Facing UNRWA}

Dr Takkenberg said that UNRWA today faces a range of issues affecting the delivery of its mandate (such as conflict, access, and funding to ensure that UNRWA carries out its responsibilities and meets expectations). These challenges also reflect the situation of Palestine refugees across the region, which is marked by instability, by conflict and by violations of basic rights under international law.

One challenge was the illegal blockade imposed by Israel entering its 11 th year in Gaza; recurring hostilities and movement restrictions entrench deepening poverty and despair. Furthermore, next year will mark 50 years of occupation of Palestinian territory, including East Jerusalem. Daily life under military occupation involves the daily risk of violence, movement restrictions, and increasingly the risk of displacement, the forcible transfer of Bedouin refugee communities, and punitive demolitions.

Another challenge is the 120,000 Palestine refugees who have fled from Syria and are grappling with life in limbo across the region and beyond, with the countries hosting them - including Lebanon and Jordan - suffering under the weight of the enormous need in this situation of crisis. While in Syria, 60 per cent of the 560,000 Palestine refugees resident in the country have been displaced, Palestinian camps have sustained severe damage and Palestine refugees struggle to survive in the ruins of Aleppo, Dera'a and Yarmouk, and increasingly in Khan Eshieh and other remote places.

Dr Takkenberg concluded by saying that after 66 years, the conflict that had triggered the establishment of UNRWA remains unresolved and, as a result, a just and durable solution to the plight of Palestine refugees remains elusive. Unlike UNHCR, UNRWA has no direct mandate to seek durable solutions and the agency's role is to continue to highlight the need to find that solution and to ensure that in its elaboration the rights and interests of refugees are safeguarded. Until a just and durable solution is achieved, the agency will continue to implement the mandate given by the General Assembly with a view to meeting the essential needs of Palestine refugees.

\section{UNRWA - Politics Disguised}

\section{Dr Einat Wilf, Washington Institute for Near East Policy}

Dr Wilf began by holding that the very existence of UNWRA distances peace. The conflict is very difficult and UNWRA is one of the causes of the failure to resolve it. The conflict is 'a tale of two returns': on the Jewish side, there is the return of people to their ancestral land. This return is a core part of their identity. It is deeply emotional for Israelis and for Jews around the world who support the Jewish state. There is also the story of Palestinian refugees who wish to return to their land and the hope of justice; this is a core part of their identity.

If either side insists that their return is more just than that of the other, the conflict will continue with no end in sight. In order to put an end to the conflict, neither side can claim superiority and both need to recognise the legitimacy of the other. On the Israeli side the settlement project is 
an expression of the return for many Jews to their ancestral homeland. On the Palestinian side the idea of return is kept alive by UNWRA. This agency is supported mostly by Western countries, with some voluntary contributions from private donors. These are all countries that support a two-state solution and the idea that Jews are in Israel by right and not might, but they reject the notion that it is a superior right. Ironically these countries continue to fund UNWRA and send a message that Palestinian return is internationally supported. Although they will deny this, the Palestinians view this as international support for their claim. If the international community maintained an equivalent policy towards the settlements, it would say to Israel: 'Please settle your nationals wherever you want because you have a strong emotional connection with the land; we will give you billions of dollars a year and we trust that when there is peace you will uproot the settlers.' This is an absurd approach, but it is exactly what those countries are essentially saying to the Palestinians in their support for UNWRA.

Each side may dream. Jews will dream about Hebron and Shiloh, and they will always be part of their identity; Palestinians will dream of Jaffa and Haifa, and they will be part of their identity. However, there is a vast difference between dreams and donating money in order to implement them. Dr Wilf stated that she would like the international community either to not prejudice either party and leave it to both sides to do their own thing (a course of action that is not helpful, in her view), or to send a forceful message to both sides that they cannot have it all, because there is another group of people here with an equal right, and both sides need to accept that neither of them will have it all: this entails not only strong policies on settlements but also, on the Arab side, curbing the Palestinian idea of the return of all Palestinians to all of Palestine. For example, UNRWA can be transferred to places where it makes sense for it to operate. In the West Bank funds should be transferred to the Palestinian Authority; in Gaza, where the vast majority are still recognised as refugees and are in need, they should be attended to by a new agency that only supports aid and does not promote the idea of return. Most people were born there and have never been displaced, but they are told that this is not their home and that their home is on the other side of the fence. Consequently, when they receive cement they do not build houses because it is not really their home; instead they build tunnels to infiltrate into Israel. Palestinians in Jordan should be made full citizens; solutions are also needed in Lebanon and Syria. Dr Wilf said that at the very minimum we need a clear declaration that the international community does not support the claim to a greater Palestine.

Dr Wilf said that the international community can take strong positions against settlements, and refuse claims beyond 1967 lines. States can withhold financial support and tax breaks; they could tell settlers that they need to hold a passport issued by Palestine, but these steps will be legitimate only if they take a strong stance with the Palestinian side; otherwise there will never be peace. For this each side must be resigned to the idea that maximalist claims are not realistic.

Dr Wilf concluded by saying that the international community needs to find a way to stop referring to non-displaced people as 'refugees', and these people should not automatically be given refugee status. Other global refugee solutions are not maintained forever, especially when dealing with millions of people. We need to separate the politics from the humanitarian, and to pressure both sides to drop maximalist claims. 


\section{Discusssion}

Participants expressed doubt whether UNWRA was the correct organisation to target. The agency does not deny that the right of return exists - and not only for Palestinians - but it does not pursue this message. Dr Wilf disputed this and claimed that there are studies that show otherwise. It was argued that Palestinian students attending schools of the Palestinian Authority have the same views as students who attend UNWRA schools; if anything, Palestinian Authority schools are far more radical than those of UNWRA. A participant noted that the Israeli argument is that Palestinians in the West Bank are, in fact, in their country. Another participant held that the international community does not accept this. If UNRWA were to be terminated, UNHCR itself would assume responsibility. If the General Assembly wished to direct it to do so, there would be an automatic majority for such a resolution. In practice, terminating in the West Bank would legally and politically bring in UNHCR to take over and that would make the claim for return much stronger. In fact, 15 years ago Palestinian refugees wanted UNHCR to take over precisely for that reason. Palestinians who are Jordanian citizens would not become UNHCR refugees. It is indeed problematic that they receive UNRWA services.

Another participant noted that it is for the states in the General Assembly that set up UNRWA to terminate the agency's mandate, or for states who are funding UNRWA, but not for the organisation itself. In the Resolution that established UNRWA, operative paragraph 1 is about the right of return. Also, with regard to the application of Article 1D, European jurisprudence recognises the refugee issues per se when it comes to Palestinians ending up somewhere in Europe.

A participant rejected Dr Wilf's attempt to create symmetry where it does not exist. There is a strong state with a functioning government, and the pressure is on the government to comply with its international obligations. Pressure on individuals is misplaced; it should be on the government that supports the individuals. Dr Wilf responded that she was not addressing UNRWA or the Palestinians, but the funding states, which have significant leeway and influence. She emphasised those because they support the two-state solution. If the donors were from Saudi Arabia there would be little scope for engagement.

It was pointed out that Israel itself has lobbied certain countries not to take away funding from UNWRA. This was because it was concerned that children who benefit from such funding would go into Hamas hands. Dr Wilf replied that indeed her critique was also directed at the Israeli government. She believes Israeli policy is deeply misguided, especially since 1967. It supports UNRWA, essentially through the Coordination of Government Activities in the Territories and the Ministry of Defence, on the assumption that it is the lesser evil. However, this is a limited, military view, which does not deal with long-term narratives. Citizens of Israel should be aware that Israel is providing UNRWA with an iron dome. UNRWA is not a military organisation, but it secures the existence of graduates who have in interest of fighting Israel based on a maximalist view of justice.

Dr Wilf disagreed that it would be political suicide to try to replace UNRWA. The international community dares not do so because the agency is a shining symbol of the commitment of the international community to support Palestinian maximalist claims. The Afghani example 
given earlier of the intergenerational mandate of UNHCR is a great example of the difference between the two agencies: UNHCR chose to grant intergenerational status; it did not automatically grant it. UNHCR prefers return, but this is only a preference. In contrast, UNRWA does not have any leeway. All refugee graphs show a peak, and then solutions are found. Of course, the intergenerational issue will be debated, but it should not be assumed. Dr Wilf called on donor states to say that irrespective of the UNGA mandate, they want UNRWA to provide aid, but not refer to the beneficiaries as refugees. A participant argued that this would not detract from their status as people who were forcibly displaced in a protracted situation. Dr Wilf said that to refer to them as refugees would then expose the politics because they retain this status only because UNRWA was created to prevent any other solution. It was commented that every refugee issue is political. This is what led MacDonald to resign: the refusal to acknowledge the politics.

A participant queried the basis for giving UNRWA aid to people in Jordan, given that their situation is better than that of many Jordanians. Dr Takkenberg responded that the UNRWA mandate does not refer to the nationality or status of the individuals, which is why they are 'Palestine refugees' and not 'Palestinian refugees'. The mandate was established during the Cold War, when the US and the United Kingdom were concerned about communist influence in Jordan, and wanted UNRWA to assist Palestinians in Jordan to counter this influence. The only service given to everyone is basic education and health. The rest (micro-business, and so on) is given on a need basis. These basic rights are where UNRWA steps in for the international community. Other participants added that in Jordan only 17 per cent of the Palestinian refugees are in refugee camps; and 75 per cent of Palestine refugees do not use UNRWA services, but Jordanian services. When they move out of the camps they do not receive services, but they maintain their status as refugees. There is no Western support for cutting down UNRWA in Jordan because there are strong security interests there, but Western financial support is not perceived as support for the right of return. During last year's financial crisis, the Prime Minister of Jordan came out in support of UNRWA continuing to provide services there.

As for the status of Palestinians in Jordan, it was noted that there are different kinds of travel document. Some people have ID numbers, some do not but nonetheless have a passport. They are not citizens.

\section{Session 6: Jewish Refugees}

What Can We Learn from the Exodus of Jews from Arab Countries?

Mr Adi Schwartz, Bar Ilan University

Mr Schwartz addressed the issue of the Jewish refugees in the context of the 1948 War, who were uprooted from their homes in the Middle Eastern states as a result of the Israeli-Palestinian conflict. He began by noting that the issue of Jewish refugees is usually neglected in the discourse of 
refugees in the Arab-Israeli conflict. He maintained that the issue was important, as it enriches the discussion and allows for more perspectives on the entire conflict to be voiced. ${ }^{66}$

Mr Schwartz began by setting out the factual framework. He said that in 1947 there were about a million Jews living in Arab countries. The largest communities were in Morocco (250,000), Iraq $(150,000)$, Algeria $(150,000)$ and Egypt $(100,000)$. He then differentiated between two different groups of community: Middle Eastern Jews (from neighbouring countries such as Iraq, Egypt and Syria); and North African Jews (mostly in Morocco and Algeria).

As for the Middle Eastern Jews, their expulsion and flight was directly connected with the 1948 War and, in fact, was one of its outcomes. Most of the Jews had left these countries by the early 1950s, and by 1952 hardly any Jews remained in those countries. In Syria, where almost 50,000 Jews had lived, they left in 1947-48. In Egypt, most left in 1948-49, and the remainder left in 1956 as a result of the Sinai War. Jews in Iraq left in 1950-51. The context of these mass population movements was the invasion of Israel by those states in May 1948. As part of the war, the states treated their Jewish citizens as enemies and, in an attempt to get rid of them, made their lives miserable and impossible. Only two days after the establishment of the State of Israel the New York Times reported that 900,000 Jews were in great danger in Muslim lands.

Mr Schwartz claimed that this maltreatment was not entirely surprising, as the Arabs had threatened before the war to do just that. For instance, the Egyptian representative in the UN said in November 1947, during the discussion over the Partition Plan:67

The proposed solution might endanger a million Jews living in Muslim countries ... If the United Nations decides to partition Palestine, it might be responsible for very grave disorders and for the massacre of a large number of Jews. Riots would break out in Palestine, would spread through all the Arab states and might lead to a war between two races.

Moreover, the Iraqi representative threatened that ' $[\mathrm{t}] \mathrm{he}$ masses in the Arab world cannot be restrained. The Arab-Jewish relationship in the Arab world will greatly deteriorate. Any injustice imposed upon the Arabs of Palestine will disturb the harmony among Jews and non-Jews in Iraq' ${ }^{68}$

The day after the UN accepted the Partition Plan (30 November 1947), the Arab population and Arab governments started to harass the Jewish population. In parallel with war breaking out in Palestine, an anti-Jewish campaign started in Arab countries. Jewish quarters were attacked and Jews were killed and injured. Bombs were thrown into their synagogues and markets;

\footnotetext{
${ }^{66}$ See also Adi Schwartz, ‘A Tragedy Shrouded in Silence: The Destruction of the Arab World's Jewry’ (2011) 45 Azure 47, 48-49.

${ }^{67}$ UN General Assembly, Ad Hoc Committee on the Palestinian Question, Summary Records of Meeting, 11 November 1947, UN Doc A/AC.14/32, 185, quoted in Ya'akov Meron, 'The Expulsion of the Jews from the Arab Countries: The Palestinians' Attitude Towards It and their Claims' in Malka Hillel Shulewitz (ed), The Forgotten Millions: The Modern Jewish Exodus from Arab Lands (Continuum 1999) 83, 84.

${ }^{68}$ UN General Assembly, Second Session, Official Records, Verbatim Record of the Plenary Meeting, Vol. II, 110th-128th meetings, 16 September-29 November 1947, 1391, quoted in Ya'akov Meron, 'Why Jews Fled the Arab Countries?' (1995) 2 Middle East Quarterly 47.
} 
Jews were sacked from their jobs; their assets were nationalised and bank accounts frozen; some were arrested, beaten and even tortured. All this was part of an orchestrated and planned action to harm the Jewish communities, which the Arab governments did not hide. Mr Schwartz noted that some of these Jews were not Zionists, especially not in any sense of political activity, and yet the Arab governments treated them as enemies. They were not seen as individuals, but as members of an ethnic group that was at war with the local population. Some, he added, were expelled, taken to seaports with only a suitcase in their hands, while others could not tolerate the atmosphere of intimidation and decided to flee.

Mr Schwartz then turned to discuss this issue in the context of peace negotiations. He said that when Israel had raised the issue of the Jewish refugees in past negotiations, Palestinians replied that it was not a bilateral issue but a multilateral issue, as Jewish refugeehood was not the fault of the Palestinians and therefore it did not directly concern them. He rejected this argument in terms of historical context, as the Jewish exodus happened because of the war - either during the war or immediately following it. The main reason for this exodus was that, by and large, the Arab world, including the Palestinian Arabs, rejected Jewish sovereignty in the land of Israel. Thus, the reason for war breaking out is the same reason why Jews were expelled from their countries. The Jews were not expelled because of internal issues, but because of the Partition Plan. These were not two separate events but part of the same war. Arab countries invaded Israel upon the request and invitation of Arab Palestinians, who were their co-belligerents. In fact, since 1946 Arab countries and the Arab Palestinians have collaborated by a decision of the Arab League to do everything possible to prevent partition. Hence, he concluded, Palestinians certainly have some responsibility for the Jewish exodus. Had they, together with the entire Arab world, accepted the Partition Plan and the notion of Jewish sovereignty, this exodus might not have happened - certainly not in the same way.

Moving to the North African group (from Morocco and Algeria, although not Libya, which has a different story), Mr Schwartz maintained that the exodus did not take place in 1948, but only when those countries were about to gain independence from France. In Algeria, where some 150,000 Jews lived, the community disappeared within a year on the eve of independence (1961). From Morocco, home to 200,000 Jews, they left in waves but mostly towards independence in 1956 (and again at the beginning of the 1960s when the ban on leaving the country was lifted).

Mr Schwartz turned to analyse the reasons for these phenomena, and pointed to the fear that was felt from the newly emerging Muslim states. The reasons reside in the pre-colonial era (until the beginning of the nineteenth century), when Jews lived in precarious conditions, endured legal and economic restrictions, and at times even suffered from physical violence. There was a religious and a legal basis in the Muslim faith and doctrine, as Jews are considered to be dhimmiwhich means 'protected persons'. They were allowed to remain and live in Muslim lands, but on condition that they accepted their inferiority. Additionally, they were obliged to pay a special tax, and suffered from many restrictions that differentiated them from Muslims. Mr Schwartz contended that this situation changed during the period of colonialism, when the French brought along the spirit of the French Revolution and ideas of equality, and Jews were partially 
emancipated and somewhat freed from dhimmi status. Jews began to leave their quarters and take government positions, a move regarded by the Muslim society as a disruption of the natural order by foreign interference, and was received with hostility and contempt. In Morocco, when the French were preparing to leave in the 1950 s, Jews were afraid they would lose their rights and colonial protection. They knew that they would be relegated to second-class citizenship subject to discrimination, and would not be seen as part of the emerging nation. This led to their flight en masse.

Mr Schwartz summed up by noting that by the mid-1960s, the Middle East and North Africa were mostly devoid of Jews, and claimed that this can be used to refute the myth that there was harmony between Muslims and Jews before Zionism. He added that those who hold this position claimed that Jews were expelled because of Zionist activity, which disrupted the equilibrium. Yet, the situation of the Jews under Muslim rule was not harmonious, and the status quo that existed was in great disfavour with the Jews. In common with other instances of subjugation throughout history (such as slavery) the situation was peaceful for as long as Jews did not attempt to change the rules.

Mr Schwartz attempted to draw a wider observation, that Zionism did in fact change the rules, and this is what brought about Arab hostility to it. The conflict, he asserted, is not merely territorial, but also involves an Arab rejection of Jewish demands to be treated as equals. The inferiority of Jews in the eyes of the Muslim world throughout the ages helps in understanding the Arab resentment of Zionism. It is hard, he added, to accept equality and sovereignty by a people which were religiously, socially and ideologically treated as inferior. This, Mr Schwartz claimed, makes for a clear moral case in favour of Zionism, as the State of Israel is a haven and the only place for Jews who originated in Arab countries, where they are entitled to freedom and equal rights.

Mr Schwartz concluded with observations about the relationship between the issues of Jewish refugees and Palestinian refugees. He maintained that Palestinians define their case as an unprecedented and unique injustice against them, and regard themselves as the ultimate victims. However, a simultaneous mass exodus of Jews occurred, for which Palestinians were responsible, at least in part. In terms of 'ethnic cleansing', he noted that he could not identify a precedent for the departure of almost the entire Jewish community, even in places that showed extreme antisemitism, like Czarist Russia. Mr Schwartz noted that the absence of any but a handful of Jews today in Middle East Muslim countries is proof of their having been forcefully displaced. Lastly, Jews are an indigenous people in the Middle East. Jews from Middle Eastern and North African countries comprise about half of the present day population of the State of Israel and, as such, have the right of self-determination. When the Ottoman Empire collapsed and the Middle East was divided into new states, Jews had the right to claim their own independence, as they constituted about 1.5 per cent of the entire population in the region. By virtue of this, Israel can be regarded as the nation state of an indigenous people which has always been a part of the Middle East. Generally speaking, Zionism can be defined as a liberation movement of an indigenous local ethnic group, which brought a solution for the centuries-old plight and discrimination of Jews from Arab countries. 


\section{Discussion}

A participant wished to put the issue in the context of political negotiations, and noted that the issue of Jewish refugees has a paradoxical character. On the one hand, Jewish and Palestinian refugees are on the 'same side' of the normative framework, as they have similar rights to compensation, and the notion of recognition and resolution is mutual. However, in practice, politics has not developed in this way. In the Palestinian narrative, invocation of the Jewish refugee issue is seen as a measure to delegitimise Palestinian claims, as a sort of defensive victimology and a psychological barrier; while, on the Israeli side, it was wielded cynically by the Israeli government. The participant surveyed the way in which the issue had developed, and mentioned that in the 1999-2000 negotiations there was one single general paragraph, which mentioned that the Palestinians would be in favour of Jewish redress elsewhere - an affiliated mechanism, but without determinative content and modalities. In subsequent landmark events the issue has not been discussed. It was not raised in the Clinton Parameters, and in Taba it was taken off the table by the Israeli side, noting that Palestinians were not directly responsible, and the Palestinians did not object to Israeli claims elsewhere. The participant considered this to be the most enlightened notion, recognising that Palestinians should not pay for grievous harm inflicted on Jews, but equally committing the Palestinians to a 'moving forward atmosphere' to support Jewish claims. In later rounds of discussions, the Israeli Foreign Ministry used the Jewish refugee issue very explicitly as a negotiating tool to offset the Palestinian side. Ironically, this resulted in Israel not furthering the matter. Nothing stopped Israel from claiming compensation from Arab countries, but the policy discourages this, so they could be claimed to balance Palestinian claims. The participant noted that normatively, using one grave offence to undercut the appropriate remedy for another population is undesirable. Two populations suffered from ethnic cleansing and atrocities and are seeking justified - although somewhat different - redress. Unfortunately there has never been a progressive discussion on the matter.

Mr Schwartz said that he was not interested in the balance described, but in bridging gaps of narratives in the long term, namely in consolidating the understanding that Jews are a local population, and hence have indigenous rights. Israel is seen as a European colonial project in the Middle East, which is a great obstacle for progression. Palestinians do not have to pay for the crimes of the Holocaust or anything else that happened in Europe, but even if no Jews had come from Europe, there would still have been Jews as a distinct ethnic group with the right of self-determination, similar to the Kurds, for instance, in the Middle East. In light of the substantial Jewish history in the region, and the issue of Jewish refugees from Arab countries in 1948, Israel should be accepted in terms of its rights and local self-determination. He stressed that seeing Israel as a coercive foreign power is a major obstacle for peace.

Another participant mentioned that Israeli domestic legislation from 2010 and 2014 concerns the expulsion of Jews not only from Arab lands, but also from Iran, which is unrelated to the 1948 context. The participant observed that it is interesting that with regard to legislation and the instruments used by the state to construct a narrative, there was no reference to the issue in the books until 2010. The laws say the state must take into account the property of and 
compensation for Arab Jews in negotiations, and mark 30 November 1947 as the day of expulsion and exit. The participant wondered why this legislation had not come into being earlier and suggested it might reflect a change of narrative, which had to do with recognising that Jewish immigration from the Middle East to Israel was not only out of national sentiments - as the Zionist narrative had claimed - but also as a result of coercion. This may affect the remedies granted. Acquiring citizenship in a state of one's own was not a remedy that Jews needed.

Mr Schwartz replied that Iran is a different case, both historically and religiously, despite certain similarities. Iran is Shi' ite, which traditionally has had a much harsher view against impurity and infidels, and there were religious rules to enforce those norms. The twentieth century is different, as the Shah was very amiable towards the West and was backed by foreign powers. However, as in other contexts, the vast majority of Jews had to flee from Iran after the Islamic Revolution in 1979 when they lost the protection they had enjoyed earlier.

As for Israeli policy, Mr Schwartz said that in both legislation and governmental practice, between 1948 and 1967 there was huge interest in both the Palestinian and Jewish refugees issue. It was dealt with heavily by the government, in the Ministries of Foreign Affairs and Justice, led by Golda Meir and Abba Even, who spoke a lot about the issue. However, since 1967 there has been the notion that the solution and the way to peace is territorial, under the 'Land for Peace' formula. As the concept of a territorial state and the two-state solution gained prominence, the international community and Israeli negotiators believed the refugees were a thing of the past, and the main topic was about territory and practical issues, and less about narratives. Only after the failure of the negotiations at Camp David in 2000 did the issue re-emerge on the Palestinian side. Interestingly, it was only in 1998, when Israel celebrated its 50th anniversary, that the Palestinian Authority first commemorated Nakba Day. Since 2000 there has been a rethinking and a restructuring of the issue. Looking into Israeli society in general, there are many reasons why Jews talk about it. Mr Schwartz recalled Professor Yazbak's earlier discussion of the silence of the Palestinians regarding the Nakba, and said that one could speak of a similar Jewish silence. People had lost their status and property and were ashamed to talk about it. Additionally, looking at the past was frowned upon in the young Israeli society, and Jews who came from Arab countries wanted to assimilate. Moreover, the Holocaust overshadowed all other atrocities. There was also a financial fear on the side of the government, as it would have had to pay compensation as Israel had no way of demanding this from the offenders. Later, there was a policy by Israeli leaders, mainly in the Foreign Ministry, to take off the table problems that were likely to complicate negotiations. An official in the Ministry of Justice was in charge of the department of Jewish claims from Arab countries, but his position was terminated by Yossi Beilin, then Minister of Justice, who said that it was irrelevant.

Another participant queried the involvement of Zionist agents in getting Jews out of Arab countries, especially from Iraq, and how the call of some countries, most notably Morocco, for Jews to return affects the claims of Jewish refugees. With regard to Iraq, Mr Schwartz said in his view it was an interesting case, as the Jewish community had been very strong and affluent, dating back to the days of Babylon. The process of departure itself happened within a single year. In March 1950, Iraq allowed Jews to leave the country on condition that they relinquish their 
citizenship. Those who left were forced to sell their property for a negligible price because they were forbidden from leaving Iraq with more than 50 dinars and a few personal possessions. A year later, the Iraqi government confiscated the assets of tens of thousands of Jews who had applied for emigration to Israel but had not yet managed to leave, so they had no choice but to leave. They were literally camped in synagogues in Baghdad, waiting to leave. There was a secret route through Iran to smuggle them out, but the situation was of enforced departure. By the end of that year, approximately 90 per cent of the Jews living in Iraq had left. The involvement of Mossad agents and a plot to hasten their departure is an unfounded conspiracy theory. In the 1970s a well-known Arab writer claimed that there had been no problems between Jews and Arabs until the Mossad threw bombs into the synagogues. An official Israeli commission of inquiry, appointed by Ben-Gurion, found no evidence for this. ${ }^{69}$ Academics who studied the matter in the 1980s and 1990s also found no evidence. Even if it were true, the explosions happened at a very late stage when most Jews had already left.

With regard to returning to Morocco, Mr Schwartz said that it is a personal decision for each Moroccan Jew. However, taking into account the history of Jewish life under Muslim rule, he was sceptical about the possibility that Jews could live as equal citizens in Morocco. Many families recount their experiences of the twentieth century, although that was under French rather than Arab rule.

Another participant mentioned that to describe the Muslim Middle East as being void of Jews is imprecise, as Jews have remained in different countries and governments have not expropriated all Jewish property. Some states use the property and allow a right of usage, but not of ownership. Arab countries, including Syria, have had secular regimes for a long time, and had been particularly keen to preserve minority rights. The participant claimed that these issues raise questions about historical doctrine and myths, and called for in-depth critical and neutral research on the matter, devoid of political motives. Mr Schwartz mentioned that the treatment of minorities in Syria is not very impressive, and said that he has doubts about the preservation of Jewish property. He mentioned that some Jews were secretly taken out of Syria in the 1990s. He also said that there is growing academic research, which for many years did not exist. The issue has been put into the Israeli school curriculum for the first time ever this year. A major obstacle for research is that there is no access to archives. The New Historians, such as Benny Morris, had access to state archives. One of the most important components for research is government policy, such as in Egypt, Iraq and the Arab League. There are secondary sources, but there is no access to archives in the Arab world. Other participants mentioned there was a need for oral histories, which could also diverge from official accounts. Mr Schwartz said there have been initiatives in this direction, but it is impossible to obtain state support for this, and most of these initiatives are carried out privately.

Another participant noted that it is highly problematic to attribute responsibility collectively. Such attribution might have merit in terms of bridging narratives, but would not stand legal

\footnotetext{
${ }^{69}$ Esther Meir-Glitzenstein, 'The Riddle of the Mass Emigration from Iraq: Causes, Circumstances, and Consequences' (1997) 71 Pe'amim 25, 26-28 (in Hebrew).
} 
scrutiny. Not only can a meaningful solution not be bilateral (Israeli-Palestinian), but it is unclear why Palestinians have any standing in the Israeli claims against the Iraqi government, for example. Only if a regional apparatus is in charge of settling the matter would it be correct from a legal standpoint to discuss those compensation mechanisms. The participant commented on the tactical use of the matter by the Israeli side in the peace negotiations, that it was offensive to the Jewish refugees themselves, and wondered whether Israel had even attempted to pursue claims against the Arab states and whether any groundwork for future claims had been carried out.

A debate developed on whether personal versus collective responsibility is a crucial issue in conflict resolution. Mr Schwartz mentioned that Jews were expelled from the Arab states for reasons unrelated to them individually, but as an ethnic group. It did not matter whether they were Zionist or not. This is similar to what happened in other contexts, such as Germany or India and Pakistan. One cannot talk about individual responsibility, but about a collective responsibility of representative bodies. The participant disagreed that this imposes responsibility on the Palestinians. Mr Schwartz explained that the Arab invasion of Israel in 1948 was by invitation from the Palestinian leadership, which had colluded with the Arab states since 1946 to jointly oppose a Jewish state. The events in Palestine and Iraq were therefore not disconnected, but part and parcel of the same thing. Had the Palestinians accepted partition, none of this would have happened and Jews could have immigrated peacefully if they had chosen to. The fact that they had to flee is specifically connected with the war, at least in Syria, Iraq and Egypt. The participant claimed that the historical link still does not impose responsibility, especially not legally, of Palestinians as a collective. Mr Schwartz replied that they are partially responsible, as part of the Arab world as a whole.

Another participant challenged the historical grounds presented by Mr Schwartz. The participant said there are historical accounts that show that Jews began to be accepted in the Arab world, or rather the Ottoman Empire, around the fifteenth century when they were fleeing from persecution in Europe, specifically in Portugal and Spain. The Ottoman Empire did not accept the Jews as equal subjects, but the policy of discrimination was also directed at other minorities, such as Christians. Equal citizenship and rights were given to everyone by the Tanzimat structural reforms of the nineteenth century, which predated colonialism. Jews and Christians alike were then considered to be subjects and, although they still suffered from absolute discrimination, the Jews saw it as a change for the better and success, and were involved in advocacy for it. The Jewish community is considered an important agent of change, and prominent Jewish intellectuals welcomed the Tanzimat, seeing themselves as part of a unified society. According to the participant, scholarship exists which claims that Zionism broke this harmonious sense and dynamic between the different communities. The participant also criticised the accounts given of persecution connected with the 1948 conflict, claiming that there are important nuances to note. In Morocco, for example, there is still a vibrant Jewish community, and during the Holocaust the king strenuously opposed the calls of the Vichy regime to send Jews to Europe. In contrast, in Algeria the Jews were perceived to be associated with the French colonisers, and this is why they fled. 
A minor argument developed over whether the way in which Jews were perceived mattered, and whether this had any effect on their status as refugees. The participants agreed that legally it did not matter why they were prosecuted, but that for historical narratives it was relevant to understand that, at least in some respects, Jews were not seen as neutral agents in a national struggle.

With regard to the Tanzimat, Mr Schwartz said that it actually strengthens the point he was trying to make. The Tanzimat took place in the mid-nineteenth century, when dhimmi status, which started in the seventh century, was abolished by decree. However, the reason was not based on good will, but as a result of pressure exerted by European powers on the weakening Ottoman Empire. This was part of the 'capitulations' by the Ottomans who were trying to mitigate external pressure.

Mr Schwartz noted, on the subject of Algeria, that Jews had lived there even before Muslims - as early as Roman times - so how, in the nineteenth and twentieth centuries, did they suddenly become 'French' or 'foreign'? When the French arrived they emancipated the Jews, causing anger among the Muslims. Mr Schwartz wondered how an indigenous community could be regarded as foreign, and claimed that it was because they had always been treated differently by the Muslim population. A participant suggested that this characterisation was related to the Jews' own identification and sympathy with the French colonisers. Mr Schwartz replied that Jews saw colonial powers as their saviours and identified with them, precisely because they gave them rights. Their identification with the French was a natural outcome of their discrimination by the Muslims.

The participant added that the depiction of all Jews as fleeing from Arab countries is incorrect, as there were widespread secret operations by Zionist operatives to smuggle Jews out, such as Operation 'Magic Carpet' from Yemen, and there was a powerful call to Jews to come to Israel, not only through expulsion. Another participant warned against implementing a double standard, claiming that it is hardly arguable that Jews, as other minorities, were in an inferior situation of structural subordination in the Middle East. The participant added that there is a very long history of systematic discrimination against Jews, and the fact that some Jews left because of a 'pull' from Israel does not vitiate the massive, state-supported atmosphere of official antisemitism in most countries. Just as we oppose issuing caveats and reducing the Palestinian experience only because not everyone was forced to leave, we should not apply the same thinking to Jewish refugees. In general, regardless of what was done to actively push Jews out, the states in the Middle East offered no effective protection and support for Jews against widespread and violent antisemitism. The participant noted that one must be careful not to delegitimise the Jewish refugee experience, which is a genuine one. There are significant differences from the Palestinian situation, but the vast majority had a 'well-founded fear of persecution' in 1948 and the early 1950s. One should not fall into a 'who suffered more' contest, but adopt a forward-looking approach in which mutual recognition of the forced displacement that occurred will be granted as the peace process and relationship evolve.

Mr Schwartz maintained that the status of Jews as refugees was recognised by UNHCR, and was repealed once they had gained citizenship in Israel. He stressed again that he was not so 
much interested in creating a balance between Jews and Palestinians as with issues of responsibility. He offered a metaphor, suggested by a Jewish Marxist philosopher, of a burning building from which a person has to jump, falling onto a person riding by on a donkey. Mr Schwartz mentioned that it was perfectly understandable why the person had to jump, but less so why the donkey rider had to pay the price. He elucidated that Jews had to flee from Europe - they had to jump from the building. However, the Palestinians are not merely passers-by in this analogy, but part of a community with a history of persecution against Jews, unrelated to the European Jewry. This is essential, he maintained, in understanding why Jews have a right to be in Israel, and understanding this narrative is crucial for resolving matters, not merely discussing technical mechanisms. The mechanism should be based on the understanding that Jews have nowhere to go back to. Accepting this might be a harder task, but is vital.

A participant replied that the metaphor of the donkey rider is incorrect. The Jews did not happen to fall on the rider; it was a systemised plan and programme that existed for many years, not a sudden fall. The participant stressed that it is indisputable that there is legitimacy in escaping the horrors of the Holocaust, but the arrival in Palestine was pre-planned. In fact, the plan continues to this day and is ongoing, focusing on pushing away Palestinians from all around Israel and Palestine outwards. The issue is not a matter of fate, and the metaphor is disrespectful towards the local population as it is too simplistic. Additionally, the participant recalled the 'nothing about us without us' motto of the movement for rights of people with disabilities. In this regard, Mizrahi Jews (from North Africa and Asia) should be part of the present session. It is not only because of shame, the participant added, that Mizrahi Jews have not spoken for all those years, but also because the Zionist movement sees itself as a Western movement, and it has silenced the language, culture and stories of Mizrahi Jews.

In a final intervention it was commented that putting narratives aside, the creation of Israel had an interesting consequence. It created two Nakbas: one for Palestinians; the other for Mizrahi Jews, whose world was destroyed by tragedy and crisis. Seeing the two groups as victims of the same event is revolutionary, regardless of issues of responsibility. This might explain why currently only two movements in the Middle East wish to associate themselves with Arab nationality and culture: one is the Palestinians in Israel and the other is Jewish Mizrahi. Only these two movements put their Arab identity at the forefront, while the rest of the Arab world wishes to move away from this identity. The participant added that there is a revival of Jewish culture and history in the Arab world today in, for example, some of the Gulf states. They try to emphasise the Jewish cultural contribution to Arab history, language, literature, poetry, and more.

Mr Schwartz concluded by stressing again his main argument that almost everyone, at least in the international community, accepts that European Jews had the right to flee and find a safe haven in Israel. However, the rights of Jews in Arab countries to flee from persecution and to self-determination are not recognised. This should be used as a tool to create a narrative that is far more plausible for Palestinians to accept that Jews are a part of this region; otherwise, Jews will always be regarded as foreigners. Palestinians should accept that Israel has a right to exist in the Middle East, and not elsewhere. 


\title{
SESSION 7: MOVIng Forward
}

\author{
Re-examination of the Premises
}

\section{Brigadier-General (Retired) Israela Oron, Geneva Initiative}

Brigadier-General Oron presented a legal historical perspective of the current laws dealing with the Palestinian refugee issue. She contended that the main, although not the only reason that the Israeli government decided to involve the issue of the Jews who came from the Arab countries was for the sake of public opinion, in order to gain support from half of the Israeli population to a peace agreement. With that as the backdrop, she established her connection as one of the legal drafters of the first Israeli government's position on the refugee issue before the Camp David Accord; and during that process the issue of refugees was to address both Israeli and Palestinian refugees.

In all attempts to deal with the hugely tragic and long-running refugee crisis, as another participant had mentioned, there is a tendency to go into the compensation issue because of its technical nature. Brigadier-General Oron recollected that for many years the Palestinians refused to talk about compensation because they felt that this would constitute abandoning the right of return, which comes first. However, ideas have changed over the past few years, and the Palestinians are not only dealing with the issues, they are also prepared to talk about compensation: who compensates, what is compensated, and the value of property laws. Political reality is often more important than legal considerations.

Brigadier-General Oron was part of the Geneva Initiative and was also responsible for Chapter 7 of the Geneva Initiative, which states that the final resolution must be discussed before resolving the refugee issue..$^{70}$ Thus the Palestinian state is a precondition to the refugee issue. The Geneva Initiative proposed resolving the issue primarily through compensation for property loss. For this there were two tracks: one fast; one regular. The Initiative also called for substantial international involvement in the search for a solution, its implementation and the resources needed. It also laid out five options for permanent residence for the refugees. Israel also was to absorb a small number of refugees. There would be massive development projects throughout the country. Afterwards, the responsibility of UNRWA would be transferred to the state.

However, Brigadier-General Oron asserted that these recommendations would not work because of the political environment. First, the possibility of there being any Palestinian state or any final status in the near future is very slim. Unfortunately, there is a growing refugee population which is causing political issues all over the world. There are also ongoing instabilities in

\footnotetext{
${ }^{70}$ Geneva Accord: A Model Israeli-Palestinian Peace Agreement, Draft Permanent Status Agreement, 12 October 2003, http://www.geneva-accord.org/mainmenu/english.
} 
our area, including in Syria, Iraq, Afghanistan and Iran. The demographics of Jordan, Lebanon, Turkey and Europe are all changing. These should be a cause for concern for many countries. Furthermore, there is a growing sense of the 'Trump effect', which probably preceded the election of President Trump - namely the hostile attitude towards immigrants and immigration, which can be witnessed in the events of Brexit and the US elections.

Brigadier-General Oron presented suggestions for resolving the refugee issue, which may facilitate a final status. She suggested treating the refugee problem separately from the establishment of the Palestinian state. We must focus first on refugees in Palestine and Jordan, which number some four and a half million, instead of all the refugees.

The plan proposed by the Geneva Initiative consists of the following:

- Compensation for refugees for loss of property will be the responsibility of Israel.

- The governments of Palestine and Jordan will take responsibility for refugees after payment of compensation.

- The government will receive funds for rehabilitation.

- The Palestinian government will resettle refugees in Area $\mathrm{C}$ in the West Bank. Refugees who move to the West Bank will become citizens and lose refugee status even though there is no state.

- Funding will be mainly by Arab countries (Gulf) and by the international community.

She then described why the plan is not likely to work:

- The Palestinian refugee issue is the main Palestinian asset in negotiations with Israel.

- The Palestinians are not likely to abandon the narrative of the right of return (although the proposal does not require it to be abandoned).

- Hamas and extreme Jihadists will object to the plan.

- Israel does not wish to compensate without an end of claims agreement.

- Lastly, the current political atmosphere of Israel is not likely to bring about this type of peace talks.

She concluded by emphasising that traditional concepts might no longer be workable, and that the linkage between a Palestinian state and the refugee issue is understandable.

Rights in Israel: 10 Years for the Arab Future Vision Documents: The Question of BI-NATIONALISM

Advocate Hassan Jabareen, General Director, Adalah - The Legal Center for Arab Minority

Advocate Jabareen spoke about the Arab future vision documents. Ten years ago, Palestinian citizens of Israel - academics, community leaders and activists - and human rights/civil society organisations published a set of 'vision documents'. These documents are important because 
they show the views of Palestinian civil society towards a shared future in Israel for Arab and Jewish citizens of the state. ${ }^{71}$

The three documents were published between 2006 and 2007 by Arab human rights organisations, Arab mayors, and Arab research centres with the participation of social, political and cultural academics, community leaders and activists. The Arab political leaders did not participate in the drafting of the documents but representatives of the political parties were present and contributed to the debates. The goal was to articulate what Arab civil society wanted, how it viewed the relationship between Israel and its leaders, as well as its concerns and rights. At the time of the conceptualisation and publication of the documents, the Knesset was holding hearings on drafting a written Constitution for Israel. Different groups, especially Jewish-Israeli groups, became active in this process of constitution making. Palestinian citizens of Israel did not see themselves as part of this process. They refused to take part in it even though they saw themselves as citizens of Israel, because they also view themselves as a national minority, and they were afforded no special status in this process. There was also a fear that the constitution-making process would emphasise the 'Jewishness' of the state; that it would end without deciding upon the borders of Israel; and that if Palestinians were to participate in the process they would indirectly give legitimacy to both of these problematic issues.

Despite the various terminologies, what the documents had in common was that they set out anti-discrimination principles, group rights for the Arab minority in Israel, and self-identification as a Palestinian Arab 'homeland minority'. They demanded not only group rights and cultural recognition, but also acknowledgement of the historical injustice against them. In this respect, they linked themselves to the Palestinian refugees, as around 25 per cent of Palestinians in Israel are 'internally displaced'. Many of the issues faced by the Palestinian refugees are similar to those faced by Palestinian citizens of Israel, and are part of the historical injustice faced by the Palestinians in general. This link between Palestinians - in Israel, in the Occupied Palestinian Territory, and the refugees in the diaspora - also brings about the question of the right of return. Part of recognising the historical injustice is to resolve the questions of full and equal rights for citizens, to end the occupation, and the right of return.

One of the most important aspects of these documents is that they recognise the right of selfdetermination for Israeli Jews. This step marked the first occasion on which Palestinian Arab citizens of Israel, civil society leaders and activists recognised the right of self-determination of Israeli Jews in Palestine.

The responses to the documents were rather negative from some groups. Among the Arab population in Israel generally there was serious debate as to their legitimacy and who authorised their preparation. Advocate Jabareen believes that the problems arose mainly because the documents emphasised aspects of secularism, which many groups, including the Islamic Movement in Israel, preferred to settle within Palestinian society. Among the Jewish Israeli public, the

\footnotetext{
${ }^{71}$ The National Committee for the Heads of the Arab Local Authorities in Israel, 'The Future Vision of the Palestinian Arabs in Israel', 2006, https://www.adalah.org/uploads/oldfiles/newsletter/eng/dec06/tasawormostaqbali.pdf.
} 
documents were attacked primarily because they negated Israel as a Jewish state, called for rescinding the Law of Return, and demanded recognition of the Palestinian right of return. They are based on a bi-national ideal: that Israel should be a bilingual and multicultural society, and recognise the Israeli Palestinians as a homeland minority group with corresponding rights, in accordance with international law.

Ten years later, Advocate Jabareen reviewed the documents and the critique. In addition to the above, the documents were criticised also for being irrelevant to Israeli Palestinians because they are based on the concept of a two-state solution. How could the documents claim both that the Palestinians are a part of the 'homeland minority' of Israel and demand the right of return at the same time? Second, there was no mention of the minority rights of Israeli Jews as, under this future vision, the Palestinians will be the majority. There was also objection to emphasising group rights when it is not known what the future holds. Maybe Palestinians will constitute the majority, and group rights should be guaranteed for Israeli Jews.

Advocate Jabareen asserted that there is a need for collaborative work between all Palestinians, in Israel and the West Bank and Gaza, and with refugees elsewhere. They need a new vision. The Nakba is now becoming the main factor in a shared political discourse of Palestinians. First it was the right of return, then the two-state solution. Bringing back the $N a k b a$ is to bring the Palestinian people back as a collective.

Advocate Jabareen suggested emphasising self-determination. There is agreement among the Palestinian people that Israeli Jews have a right to self-determination in Palestine. Hamas did not object to the principle, but the question is whether it is an appropriate time to recognise it when there is no reciprocal recognition by Israel. Other Islamist organisations have argued the same. This is similar to the critique by Edward Said: that the Palestinians gave up their last card in the game.

One of the obstacles faced by the Palestinian Authority is that it cannot mobilise the population to support a two-state solution. When they acquired de facto recognition of a Palestinian state by the UN General Assembly in 2012, ${ }^{72}$ the Palestinian population did not see it as a cause for celebration. However, two years earlier, when President Mahmoud Abbas spoke about the Nakba, the Palestinian public regarded him as a hero.

It is necessary, therefore, to speak about rights before discussing the partition of Palestine. To speak of self-determination for the Palestinian people is to speak about living in equality and dignity and recognising historical injustice in Palestine. Partition should be put off until later. To the critique that he is running ahead of himself, Jabareen answered that this is because of the lack of consensus on partition. The debate should be on self-determination and what it means for rights. The discussion should be premised on civil and political rights for all.

Advocate Jabareen concluded that perhaps a lesson from these documents is the need to find common points of departure - in this case, the self determination of Israeli Jews and Palestinians and the concept of rights. The second stage would then be to talk about partition. Since all of the debates have been constrained by the question of partitioning, there are inevitable conflicts within

${ }^{72}$ UNGA Res 67/19, Status of Palestine in the United Nations (4 December 2012), UN Doc A/RES/67/19. 
the documents. The proposal is for the concept of self-determination to take the lead while ensuring civic and political rights for Israeli Jews and Palestinians, not only collectively but also for individuals. The partitioning of the territory should be addressed at a later stage.

\section{The Claim for Justice and the Truth Commission for the 1948 Refugees}

\section{Dr Daphna Shraga}

Dr Shraga proposed the establishment of a historical truth commission for the 1948 refugees. She began with two general remarks on the Palestinian 'claim for justice' and the theory of 'barriers to peace'. The Palestinian claim for justice, first put forward in Oslo in 1993, demanded that Israel acknowledges its responsibility, both moral and legal, for the plight of the Palestinian refugees, and offers redress ranging from apology to restitution, compensation and, above all, recognition of the right of return. This claim, flatly rejected by Israel in Oslo in 1993, was put forward again in subsequent meetings at Camp David (2000) and Annapolis (2007-08). By then Israel was willing to offer some expression of regret, 'recognition of suffering' or 'acknowledgement of pain', but not an apology or any assumption of responsibility. What for Israel was the maximum that it was willing to offer was not even the minimum that the Palestinians were hoping for or willing to accept.

Dr Shraga then commented on Professor Bar-Siman-Tov's theory of 'justice as a barrier to peace'. ${ }^{73}$ According to this theory, where justice is a barrier to peace and the gap between the parties cannot be bridged, the parties should attempt to delink the claim for justice from the peace process, strive to reach a peace agreement first, and agree to deal with the claim for justice at a later reconciliation stage. In the Israeli Palestinian context, Bar-Siman-Tov argued, the Palestinian claim for justice had plagued the two-decade negotiating process and brought it to a halt. To remove the barrier to peace and, at the same time, ensure that the claim for justice is dealt with at the reconciliation phase, the parties would have to agree in the peace agreement to postpone the resolution of the claim for justice until after its conclusion.

Dr Shraga criticised this proposal on several grounds. First, there is little to suggest that the Palestinians would be willing to defer consideration of their claim for justice until after the conclusion of the peace agreement. Second, if the claim for justice is truly a barrier to peace, then it cannot simply be removed; for it to be removed it has first to be resolved. Third, in an atmosphere of mutual distrust, and given the history of broken promises, the likelihood that the Palestinians would agree to defer the resolution of their claim for justice on the basis of a promise is small. In her view, dealing with the claim for justice should not necessarily be linked to the peace process; it should rather precede it. Dr Shraga's critique of the theory of justice as a barrier to peace

\footnotetext{
${ }^{73}$ Yaacov Bar-Siman-Tov, 'Justice and Fairness as Barriers to the Resolution of the Israeli-Palestinian Conflict' in Yaacov Bar-Siman-Tov, Barriers to Peace in the Israeli-Palestinian Conflict (The Jerusalem Institute for Israel Studies 2010) 178.
} 
brought her to recommend that a historical truth (and reconciliation) commission be established ahead of the negotiating process, focusing on the problem of the 1948 refugees in all its aspects.

The historical truth commission, provisionally titled 'the 1948 Commission', would investigate the events of 1948, the War of Independence for the Jews, and the Nakba for the Palestinians. It would deal with the Palestinian claim for justice ahead of the negotiations and in an atmosphere free from political pressure, so that by the time the peace process resumes and the claim arises again, the negotiators, both Israelis and Palestinians, would have the benefit of an objective factual report. Informed by the conclusions of the Commission, the parties would negotiate on the basis of knowledge of the facts of the 1948 events, and not, as has hitherto been the case, on the basis of ignorance. The Commission's well-researched report and conclusions would provide a basis for reconsideration of Israel's role in the plight of the Palestinian refugees, and of its readiness to offer an apology or other expressions of regret. Dr Shraga said that the establishment of the 1948 Commission to unveil the truth about the 1948 events may at this point be an imaginary scenario (for all the reasons that had been elaborated by Brigadier-General (Retired) Oron), but within this imaginary scenario, the proposal hopes to tackle some real challenges.

The main characteristic of the 1948 Commission and its greatest challenge is the absence of a formal legal basis for its establishment. Unlike most truth and reconciliation commissions established by law or agreement, the 1948 Commission would be established outside any legal framework. The Commission would have to rely on its perceived legitimacy as it cuts across all aspects of the Commission, from the moment of its establishment, throughout its operation, until the submission of its report.

The establishment of the Commission should be preceded by a broad-based consultation process, a necessary preliminary step, according to the toolkit on National Consultation on Transitional Justice (2009) of the UN Office of the High Commissioner for Human Rights. ${ }^{74}$ The process of consultation should be led by an NGO coalition with the purpose of informing the two societies of the proposed Commission and seeking their views on the propriety of the Commission, its mandate, composition and expected outcome. It is on the basis of the views and expectations expressed by the public that the Commission would be designed. It was, in fact, largely on the basis of a two-year consultation process that the Truth and Reconciliation Commissions in South Africa and Sierra Leone were designed.

Dr Shraga then set out the mandate of the proposed Commission, its subject matter, temporal and personal jurisdiction. The mandate would be to investigate the 'events of 1948', which are broader than the plight of Palestinian refugees and would include some constituent events, such as the Dir Yassin massacre. The temporal jurisdiction of the Commission would begin in 1947 and continue until some time in the 1950s. The term ' 1948 ' is therefore conceived not necessarily as an indication of the year, but as a symbol for the 1948 events.

\footnotetext{
${ }^{74}$ Office of the United Nations High Commissioner for Human Rights, Rule-of-Law Tools for Post-Conflict States: National Consultations on Transitional Justice by the United Nations Office of the High Commissioner for Human Rights, 2009, http://www.ohchr.org/Documents/Publications/NationalConsultationsTJ_EN.pdf.
} 
As for the personal jurisdiction, Dr Shraga recommended a broader understanding of the term 'refugees' to include not only the Palestinian refugees, but also the internally displaced 'absentees' and Jewish refugees from Arab countries. The inclusion of Jewish refugees as part of the broadly conceived mandate of the 1948 events will reflect even-handedness in dealing with the events of 1948, and enhance the legitimacy of the Commission in the eyes of the Jewish society.

To convey legitimacy, the composition of the Commission must be balanced and representative of the many segments of both societies. It should be gender balanced, and include both Arabs and Jews, former judges and politicians, historians and religious figures. Premised on the assumption that, in the circumstances now prevailing, there is little likelihood that the 1948 Commission would be established by the government, it is envisaged that it would be established by civil society with wide support from public institutions - academia, the Office of the President and the NGO community, including, in particular, Jewish and Palestinian refugee organisations.

The process of collecting evidence and hearing testimonies - another important element in the build-up of the legitimacy of the Commission - should be transparent. With the passage of time there would be fewer living testimonies of both Palestinian and Jewish refugees and combatants. Increasingly, therefore, the Commission would have to resort to written documents, evidentiary material and testimonies provided by historians and political scientists.

Dr Shraga noted that in recent years the Nakba has emerged as a legitimate subject of discussion. The academic debate has spilled over to the press, the cultural space, the plastic arts and the fringe theatre. While it has not yet trickled down to society at large, there is nonetheless a sense of awakened interest.

Dr Shraga concluded by saying that managing the expectations of both Jewish and Palestinian communities would be one of the many challenges facing the Commission. In setting out its purposes, it would have to be made clear that the Commission is not mandated to recommend practical solutions for the Palestinian refugee problem (that would be a matter for the negotiating peace process); nor would it be expected to create an agreed narrative or even create a 'historical truth', but to give a platform for both narratives, recognise their legitimacy and, in so doing, narrow, however slightly, the narrative gap.

\section{DisCUSSION}

Responding to a question about individual rights, Brigadier-General (Retired) Oron said that in the compensation system in the Geneva Initiative, the individual rights are taken care of by compensation for property. Both sides will commit to an end of claims, which will be endorsed by a UN resolution. Some participants emphasised the distinction between the substantive right and the remedy. The PLO or Israel cannot waive the rights of others, but there will be no forum through which to make a legal claim. Another participant added that there is a time lag, which also makes individual claims unlikely. The possibility of turning to other tribunals will not be available. Another participant maintained that the continuity of individual rights is helpful rather than a problem. It allows the Palestinian side to say on return: 'Even though we've 
negotiated away the right of return, you still maintain an individual right that cannot be extinguished in any way'. With regard to compensation, it is not clear that the right continues to exist, but again people might want to hold off until a better mechanism emerges.

Brigadier-General (Retired) Oron added that the criticism of many of the Geneva Initiative documents is that they are too technical, so it is now working on a project called 'Dealing with the Past', which is intended to address this. Another participant disputed that the right of return is only symbolic: it is deeper than that, and has to do with individual claims.

Responding to a question on mechanisms, Advocate Jabareen said that the political crisis of thought on the Palestinian side led to his suggestion to speak of the right of self-determination. This direction might offer new angles on many subjects. For example, the right of return of Palestinian refugees, if it is right, has individual and collective aspects to consider, as well as remedies. There are cases before the High Court of Justice concerning uprooted villages, in which people have been offered compensation and they refused. The concept of the right of return was disconnected from the right of self-determination, and when the PLO speak of return, they speak about return to the homeland. Reference to self-determination resolves this dilemma for many Palestinians. The struggle of Palestinians is to remain where they are. Let us return to this question. When the PLO was founded, it spoke about self-determination, but it has stopped doing so. Advocate Jabareen said that he was not suggesting any specific mechanism, but a new way for Palestinian political thought.

A participant disputed that the claim for self-determination is an aspiration for a homeland. This is clear from the documents.

Commenting on the notion of a truth commission, a participant said that the conflict would not be resolved by knowing each other's narrative. This knowledge is good for education, when we achieve peace. The link between the Palestinian people and Israel is the most intimate connection. Palestinians know the Israeli narrative very well; they speak Hebrew, but they do not accept it, and this has political consequences, such as two states. As for Israelis, you can expose them to the Nakba, and they will have an answer for you - we had no choice but to create Israel. Narrative does not resolve the conflict - not in South Africa, nor in Northern Ireland. Intellectually and academically it merits support, but narratives do not resolve conflicts. Abu Mazen said, a fortnight earlier, that dialogue with Israelis is important. Israel is the Palestinian's enemy, and we want to achieve reconciliation with the enemy. Resolving conflicts is not based on recognising the other's narrative.

To a question on challenges to the proposal for a commission, Dr Shraga responded that the immediate problem is kick-starting - how to find the people who will support the Commission, how to convince them that it is possible. Funding will be a big problem, as a commission is a costly operation, although money is never an issue when there is political interest. The problem of legitimacy must be taken into account in every step of the Commission's operation. In designing its composition, an overly wide range might risk paralysis. A balance should thus be struck between the Commission's representativeness and its efficiency. She maintained that there is an acute need to educate the Israeli Jewish population, both the younger and the older generations. 
A participant asked why limit the mandate to 1948 and disregard earlier events. Dr Shraga responded that the Commission is not designed to investigate the origin of the conflict, but rather the single most important constituent event in the contemporary history of the Israeli-Palestinian conflict. The Commission, however, would be free to put the 1948 events in a much larger historical context.

Brigadier-General (Retired) Oron noted that the Geneva Initiative's 'Dealing with the Past' project is about fact finding, with the intention of understanding and seeing how we can live with our narratives and move towards an agreement. It was designed as a tool for negotiators that 'soft/solved' issues would be agreed in advance and embedded into the agreement. It has not been published because of sensitivity on both sides.

With regard to the proposed commission, a participant commented that it is politically unfeasible on the Palestinian side to divide the refugee problem with other parts of the peace negotiations. However, a UN Security Council resolution that sets out parameters for a solution, which contains elements for dealing with the refugee issue, would have been useful ten years ago, although its time might now have passed. The participant added that the idea of an unofficial truth commission, with sufficient legitimacy on the basis of the composition of its members and how it operates, is very interesting and powerful. However, a huge potential challenge is if the Commission were to fall apart critically. Would failure produce more harm in the relationship between the two sides?

Another participant said that it is a great idea for people to sit together and talk. To put together refugees and Israeli officials is a greater challenge. It is therefore a good idea to start with civil society. The names mentioned, including the President of Israel, are regarded as complicit in the colonial project. If you speak with civil society there is less of a power gap. There are initiatives like Zochrot, which are not welcome in Israeli society. There is a further dangerous issue with holding the Commission before establishing a Palestinian state. The experience of Oslo and state recognition is the first case in history when a state was established while under occupation. This is why it is such a failure. It only leads to atrocities. One might not want to experience the same thing and undermine the chance for reconciliation. One cannot discuss narrative while there is still occupation.

Dr Shraga said that peace with Palestinians, unlike with Egypt or Jordan, carries a price for Israel. Israelis will be looking at the removal of settlements. Can we expect Israelis to have the emotional space for refugees under these circumstances? That is why we need to talk about the refugees ahead of time.

Dr Shraga said that the Truth Commission established by Zochrot triggered little reaction and, in practice, was disregarded. Being on the far left of the Israeli political spectrum, it did not enjoy, and probably did not seek, legitimacy in the public eye. As for the timing of the 1948 Commission, she added that on the assumption that the peace agreement with the Palestinians would entail the removal of settlements, it is difficult to see how Israelis would have the emotional space to empathise with the 1948 Palestinian refugees at the same time; hence the proposal to establish the Commission ahead of the peace agreement. 


\section{CONCLUSIONS}

\section{Professor Guy Goodwin-Gill Professor Yuval Shany}

Professor Goodwin-Gill noted that the term 'refugee' now carries much greater weight than it did in 1948. It invokes the right of return and various human rights. It also distorts some of the discussion. We can invoke the right of return on an individual basis, but rights can be compromised by agreements between states. They can also be fulfilled through inter-state agreements, such as the UN Compensation Commission. There are encouraging examples of what can be achieved, but the compensation issue is not going to disappear. Experience suggests that there must be an individual element for any compensation agreement to be reached. We speak of loss of property, but there is also loss by refugeehood. There are also types of injury, although this may be less relevant as those who are entitled to claim this may be passing away. So we are left with compensation for property.

The right to return has an individual dimension, but it is entangled in the right of selfdetermination. Therefore, it can be moderated within the realisation of the greater right, that of self-determination.

Professor Goodwin-Gill agreed with the point made by Brigadier-General (Retired) Oron about politics taking priority over law, as is the developing international attitude towards refugees worldwide. Needs are growing, states are less willing to approach issues with an international inclination and recognise the need to resolve the issues internationally rather than unilaterally. Professor Goodwin-Gill concluded by noting that narratives impact on legal interpretation. He expressed hope that narratives can come together.

Professor Shany noted that the topics discussed in the workshop are rarely talked about in academic settings. He had expected participants to speak across each other, but was surprised to discover that there was little disagreement on many historical and moral issues, and even on legal issues. There was consensus that the establishment of the state resulted directly or indirectly in the Nakba. The information on the decision not to allow return was an extremely important insight. It sheds new light on the relevance of the 'expelled or fled' issue. It also invites the notion of shared responsibility. There is also consensus that property left behind needs to be compensated for, irrespective of whether or not return was permitted. Individuals should not carry the burdens of the political decision.

As for the right of return, most speakers did not construe UNGA Resolution 194(III) as entitling return to the exact place but as an abstract notion of a flexible mode of implementation. In that case, he saw room for hope that the problem is not so intractable.

At the same time, there is also a less hopeful side. We are stuck in time, frozen no less than the former Caucuses and with millions of people involved. We need to find a way out of the deadlock. Some paths have been discussed: compensation, return, taking people off the refugee list through nationality and resettlement, the role of UNRWA in this context. In these times, as 
Professor Goodwin-Gill said, given international attitudes, there is little scope for optimism. We are dealing with dysfunctional entities (Palestinians and problems in Israel).

Other participants agreed that the discussion was stimulating and informative, and should have a ripple effect as there is not enough discussion in Israel of the 1948 refugees issue. In three decades there have been only a handful of events, mostly in Tel Aviv University. One participant expressed strong pessimism with regard to the likelihood of a political settlement in the near future, not because we do not know what it would look like, but because there is no political will for it. The participant said that, hopefully, future generations will be pushed into resolving these issues, and then a document like the proceedings of the workshop needs to be made available so that they do not need to start from scratch. That might form a basis for movement towards settlement in the future.

Another participant emphasised that there is transformation in the Palestinian thinking on the right of return. It remains the cornerstone of demands, not as a practical demand but rather as a cry for justice and increasingly for an acknowledgement of rights. If a two-state solution is becoming less feasible, rights discourse becomes the default. Another participant added that addressing the fundamental problems such as the refugee issue is crucial for achieving peace.

A participant highlighted that, for the Palestinians, an offer of compensation as the only remedy creates immediate antagonism and rejection, because it conveys a rejection of their claim for justice and equality in their homeland. They are recognised as individual victims only. The justification not to allow return is to maintain Israel as a Jewish state. This means that Jewish selfdetermination is more important than Palestinian self-determination in Palestine. The remedy need not necessarily be return to the villages, but when there is no recognition of a demand at all, people demand the maximum: I want my village back. If there is a process of genuine recognition that this place is the homeland of both people, then the precise location becomes secondary. This is the story of South Africa. People did not return to their places of origin, but this was not perceived as evil, because people accepted the needs. Once there is recognition, the issue will become pragmatic. Now it is principled because the rejection of recognition is principled.

Rapporteurs: Amit Haim, Grace Jin, Elchanan Segal 